\title{
VOTING TECHNOLOGY AND DEMOCRACY
}

\author{
PAUL M. SCHWARTZ*
}

\begin{abstract}
The 2000 presidential election exposed a voting-technology divide in Florida and many other states. In this Article, Professor Paul M. Schwartz critiques this phenomenon from the perspective of systems unalysis. He considers both technology and social institutions as components of unified election systems. Schwartz first examines data from the Florida election and demonstrates the central importance of feedback to inform voters whether the technology they use to vote will validate their ballots according to their intent-an advantage he finds distributed on unequal terms, exacerbating built-in racial and socioeconomic bias. Schwartz then turns to the various judicial opinions in the ensuing litigation, which embraced competing epistemologies of technology. He suggests that judges who favored a recount saw election technology as a fallible instrument for converting voters' choices into votes, while the U.S. Supreme Court majority trusted machines over fallible humans and required hard-edged rules to cabin discretion and avoid human imperfections. Finally, the Article concludes with a review of efforts to reform the unequal distribution of voting technology. Schwartz finds that some efforts at litigation and legislation show promise, but in many instances they are stalled, and in many others they exhibit shortcomings that would leave the voting-technology divide in place for future elections.
\end{abstract}

In the 2000 presidential election, voters in Florida's Gadsden County had a sixty-eight times greater chance of having their votes invalidated than voters in adjoining Leon County. ${ }^{1}$ Gadsden County, which is Florida's only majority-black county, depended on unreliable voting technology, while Leon County, a majority-white county, benefited from state-of-the-art voting machines. ${ }^{2}$ As this dramatic example suggests, there was a "voting-technology divide" in Florida during the November 2000 election. This example also suggests that differences in voting technology have the potential to alter the outcome of elections: Over 2000 ballots were invalidated in the majority-black

* Professor of Law, Brooklyn Law School. An earlier version of this Article was presented at Columbia Law School to Professor Wendy Wagner's Regulation and the State class and at the University of Indiana School of Law-Bloomington to a faculty forum. I am grateful for the helpful responses in both fora as well as the comments and assistance on previous drafts from Michael J. Gerhardt, Edward Jacob Janger, Lance Liebman, Lynn LoPucki, William McGeveran, Judith Salzman, Chanani Sandler, Laura Schwartz, Peter Spiro, William Michael Treanor, Wendy Wagner, Benjamin H. Warnke, David Yassky, and Melodie Young. A grant from the Dean's Scholarship Fund of Brooklyn Law School supported my work on this Article. As always, Stefanie Schwartz supplied essential inspiration. (C) Paul M. Schwartz, 2002.

1 See infra Part I.B.1; infra Table C.

2 For a description of voting conditions and voting technologies in the two counties, see infra Part I.B.1. 
county in an election decided by only 537 votes. ${ }^{3}$ Beyond Florida, a similar gap in access to election technology is found throughout the United States; only nine states voted with uniform or nearly uniform statewide technology in November $2000 .^{4}$

The presidential election ended with the Supreme Court's 5-4 opinion in Bush v. Gore, ${ }^{5}$ which has already generated an enormous amount of scholarly attention focusing on a range of issues. ${ }^{6}$ But the Court's approach to election technology, and the broader normative

3 The Governor's Select Task Force on Election Procedures, Standards and Technology, Revitalizing Democracy in Florida 31 (Mar. 1, 2001) [hereinafter Florida Task Force], available at http://www.collinscenter.org/index.htm. In contrast to over 2000 invalid (or residual) ballots found in Gadsden County, only 181 residual ballots were found in Leon County, which had almost six times as many voters.

4 The Caltech/MIT Voting Technology Project, Residual Votes Attributable to Technology: An Assessment of the Reliability of Existing Voting Equipment 4, at http:// www.vote.caltech.edu (Mar. 30, 2001) [hereinafter Caltech/MIT, Residual Votes] ("The states with complete or near uniformity are New York and Connecticut with lever machines; Alaska, Hawaii, Rhode Island and Oklahoma with scanners; Illinois with punch cards; Delaware and Kentucky with electronics.").

5531 U.S. 98 (2000) (per curiam).

6 Some reading the Bush decision have perceived heavy-handed partisanship in the majority, while others saw the dissenting justices and their supporters undermining confidence in the Court with their accusations against the majority. See William Glaberson, Court Battle for Presidency Rages On in Legal Circles, N.Y. Times, Feb. 1, 2001, at A14 (describing heated debate between two dueling interpretations).

Judge Richard Posner has advanced a "pragmatic" justification for the decision, arguing that the majority took practical consequences into account and avoided a national crisis. See Richard Posner, Breaking the Deadlock 172-89 (2001) [hereinafter Posner, Deadlock]; Richard Posner, Florida 2000: A Legal and Statistical Analysis of the Election Deadlock and the Ensuing Litigation, 2000 Sup. Ct. Rev. 1, 40-48 (2000). In a critical review of Posner's book, Richard Hasen responded, "For Posner, law exists as something real when he can use it as a club to beat down the Florida court, but it is a convenient facade for the U.S. Supreme Court to give legitimacy to its pragmatic role in preventing a crisis." Richard L. Hasen, A "Tincture of Justice": Judge Posner's Failed Rehabilitation of Bush v. Gore, 80 Tex. L. Rev. 137, 138 (2001) (book review). Hasen described Posner flipping "his 'pragmatism' switch on or off to serve his end result." Id. at 152.

Another exchange of contrasting views can be found in the prominent debate between Ronald Dworkin and Charles Fried, played out in the pages of the New York Review of Books. See Ronald Dworkin, A Badly Flawed Election, N.Y. Rev. Books, Jan. 11, 2001, at 1 [hereinafter Dworkin, Badly Flawed] (calling Bush per curiam order "one of the least persuasive Supreme Court opinions that I have ever read"); Charles Fried, "A Badly Flawed Election': An Exchange, N.Y. Rev. Books, Feb. 22, 2001, at 8 ("I see the Court as having reluctantly done the job its commission required of it."); see also Ronald Dworkin, 'A Badly Flawed Election': An Exchange, N.Y. Rev. Books, Feb. 22, 2001, at 8 [hereinafter Dworkin, Response to Fried] (arguing that Fried's response "does not provide the defense I had hoped for, and his failure will only deepen suspicion that no decent defense can be found").

Some of the best scholarly analyses of Bush $v$. Gore are contained in special issues of two law reviews. See Symposium: Bush v. Gore, 68 U. Chi. L. Rev. 613 (2001); Election Law Symposium, 29 Fla. St. U. L. Rev. 325 (2001). The Florida State University Law Review has also posted its symposium online at http://www.fsu.edu/journals/lawreview/backissues/vol29/issue2.php. 
question of the proper use of voting technology in a democracy, have been largely ignored. This Article uses the Florida election system of November 2000 and the ensuing Bush litigation as a springboard for exploring the issues of election technology and democracy.

In Part I, this Article begins its analysis of voting technologies and their legal implications by examining the Florida election of November 2000. Drawing on the available data about the election, this Part presents a disturbing finding: The deployment of election technologies created a voting-technology divide in Florida. Florida employed five voting technologies that differed in the amount of feedback they provided to voters as ballots were cast. Voting technologies on the good side of the technology divide provided greater feedback to the voter about whether or not her ballot would be counted. This Part also explores the racial and socioeconomic dimensions of the voting-technology divide. Technological differences guaranteed unequal access to voting on November 7, 2000.

Part II and Part III evaluate the Florida Supreme Court's opinion in Gore v. Harris ${ }^{7}$ and the U.S. Supreme Court's Bush v. Gore ${ }^{8}$ opinion reversing the Florida court, respectively. This Article finds that these two judicial opinions exhibit competing epistemologies of technology. For the Gore majority of the Florida Supreme Court (and the Bush dissenters of the U.S. Supreme Court), the truthfulness of decision-by-machine ultimately depended on human scrutiny. I term this belief "technological subsidiarity." These judges complemented it with a belief in "technological fallibility." In discussing and defending this second belief, they confronted the issue of unequal access to vot-

For a sampling of views found elsewhere, see, e.g., Alan M. Dershowitz, Supreme Injustice: How the High Court Hijacked Election 2000 (2001) (arguing that Court's majority let its desire for particular partisan outcome take priority over legal principles); Howard Gillman, The Votes that Counted 189 (2001) (arguing that five justices in majority "made a decision that was consistent with their political preferences but inconsistent with precedent and inconsistent with what would have been predicted given their views in other cases"); The Vote: Bush, Gore, and the Supreme Court (Cass R. Sunstein \& Richard A. Epstein eds., 2001) [hereinafter The Vote] (collecting essays presenting diverse analyses); Michael J. Klarman, Bush v. Gore Through the Lens of Constitutional History, 89 Cal. L. Rev. $1721,1727,1761-64$ (2001) (suggesting that although "Bush v. Gore reveals partisan preferences trumping law" it is unlikely to have significant long-term impact on Supreme Court's reputation); Larry D. Kramer, The Supreme Court in Politics, in The Unfinished Election of 2000105,152 (Jack N. Rakove ed., 2001) (concluding that decision is "an extreme instance of a regular pattern of judicial assertiveness that reflects the justices' mistrust of politics and their assumption that on most important questions they know better and that the rest of us are not to be trusted"); Bruce Ackerman, Anatomy of a Constitutional Coup, London Rev. Books, Feb. 8, 2001, at 3,6 ("The actual opinion of the Court in Bush v. Gore is a shabby affair. The majority's conclusion does not follow from its premises.").

7772 So. 2d 1243 (Fla. 2000) (per curiam).

8531 U.S. 98 (2000) (per curiam). 
ing technology and justified judicial intervention as a response to the unfairness in deployment of election technology. While they had an incomplete understanding of voting technology in Florida, their instinct was correct: The Florida election system in 2000 had built-in unfairness that justified judicial intervention.

Part III shows how the U.S. Supreme Court's per curiam opinion in Bush (and the dissent in the Florida Supreme Court's Gore case) worried about human fallibility instead. This competing epistemology of technology is one in which voting technology is generally precise and fair, and humans bring with them the threat of inaccuracy and partisan passion. The U.S. Supreme Court's requirement of fixed rules for recounts dovetails neatly with this belief system. Its per curiam opinion revived the classic legal dichotomy between rules (hard-edged benchmarks) and standards (more open-ended benchmarks).9 If technology left ballots unexamined in Florida, the gray zone in which the ballots existed was to be navigated with rules lest the recount go astray. The Bush Court declared that the Equal Protection Clause demanded such rules for statewide recounts.

Part III argues that this enshrinement of rules over standards fails to address two problems. First, this requirement does nothing to close the technology divide. For example, it does not help the voters in majority-black Gadsden County relative to the adjoining county with a white majority. In fact, the Supreme Court's vision of "equal protection" safeguards only those citizens who vote with better technology and who have already survived the technology obstacle course. Second, inflexible rules for vote recounting will allow state election officials to respond to a close election only if technology fails in exactly the same way as it did in Florida in November 2000. If, as is more likely, different and unanticipated failures occur, there normally would be a recourse to more general standards. After the Bush decision, however, no remedy would be possible because only rules are constitutionally permissible.

Part III concludes by arguing that Chief Justice Rehnquist's concurrence in Bush favored the technological "haves" even more than the per curiam opinion. Rehnquist interpreted Florida law as intending to leave uncounted the ballots of voters who failed to follow voting instructions. In this fashion, voters who are assigned bad vot-

9 In 1985, Pierre Schlag observed that every generation of legal scholars appeared fated to revisit the rule-standard distinction. Pierre Schlag, Rules and Standards, 33 UCLA L. Rev. 379, 380 (1985) ("As members of the legal community, we are forever involved in making arguments for or against rules or standards."). Even Schlag did not predict, however, that the outcome of a presidential election one day would turn on the rule-standard dichotomy. 
ing technology can be penalized further if their executed ballots have flaws in them. This approach, based on a fanciful interpretation of the applicable state law, creates an incentive for gamesmanship by election officials when designing election systems.

Having examined the voting-technology divide in Florida and its judicial treatment in Gore and Bush, I turn in Part IV to the question of what should be done about such built-in inequality. In Part IV.A, I advocate recognition of a right to equality in access to election technology and other vital aspects of election systems. Equal access to voting technology matters both to permit individual participation in government and to allow the voice of the people to be heard. I also argue that "political lockup" can allow unfair conditions in the deployment of election technology to persist over years and even decades. Although judicial review should not form the exclusive solution, it is needed as part of ongoing action to prevent electionsystem design from institutionalizing unequal access to the franchise. I suggest that the particular focus of litigation to end the voting-technology divide should be on the Equal Protection Clause and section 2 of the Voting Rights Act.

Finally, Part IV.B reviews legislative proposals for election reform made since the Supreme Court's Bush decision. While Congress, after some hesitation, has moved to consider reform bills, their principal features are inadequate in several respects. Only three states have adopted laws to reform their election systems, and the improvements made in two of those states, Florida and Georgia, also exhibit shortcomings. ${ }^{10}$ The time has come to dismantle the votingtechnology divide in the United States, but the reform that this Article proposes in Part IV has yet to occur.

\section{I.}

\section{Election Systems and Feedback in Voting}

In his classic history of technology in America, Thomas P. Hughes defines technology as "the effort to organize the world for problem solving so that goods and services can be invented, developed, produced, and used."11 In the election of 2000, the task for Florida-and all states-was to solve a particular problem: registering the will of voters regarding their choices of candidates for public

10 On a more positive note, however, the reform in Maryland has improved an already good voting system. See infra notes 329-31 and accompanying text.

11 Thomas P. Hughes, American Genesis: A Century of Invention and Technological Enthusiasm 1870-1970, at 6 (1989) (emphasis removed). 
office. Florida and other states turned to technology to execute these tasks: ballots for recording votes and machines for counting votes.

We can think of this technology and its associated public institutions as forming one "election system" for completing the task of recording the voter's will. In studying how the components and subparts in this larger system fit together, this Article adopts the methodology of systems analysis. ${ }^{12}$ As Lynn LoPucki, the leading proponent of systems analysis in the American legal academy, has explained: "To analyze a system is to break it down into its component parts, and to examine how those parts relate to one another and contribute to the functioning of the whole. The emphasis in systems analysis is on relationships rather than on the component parts themselves."13 Systems analysis is well-suited for attempts to improve technology; it views machines and social institutions alike as parts of organized larger systems and it seeks to understand and ameliorate inconsistencies in system design and performance.

On November 7, 2000, voting in Florida, as elsewhere in the United States, took place in a state election system with different elements. In general, each state election system had three aspects: (1) voting technology (voting machines, assorted ballots for the different machines, and ballot counting machines); (2) associated public institutions and personnel that manage the technology and perform other necessary tasks; and (3) different statutory constraints that shape the selection, maintenance, and design of the technology and the behavior of the public institutions and personnel.

One of the predominant characteristics of the Florida system in November 2000 was the heterogeneity of its voting technologies. ${ }^{14}$ In this regard, Florida is similar to most American states. ${ }^{15}$ In most states, counties or other municipal entities are permitted to select equipment from a list of approved, or "certified," voting systems that the state division of elections or similar entity maintains. Florida used

12 For an excellent anthology of writings regarding systems analysis, see Systems, Experts, and Computers: The Systems Approach in Management and Engineering, World War II and After (Agatha C. Hughes \& Thomas P. Hughes eds., 2000).

13 Lynn M. LoPucki, The Systems Approach to Law, 82 Cornell L. Rev. 479, 487 (1997) [hereinafter LoPucki, Systems Approach]; see also Lynn M. LoPucki, Should the Secured Credit Carve Out Apply Only in Bankruptcy?: A Systems/Strategic Analysis, 82 Cornell L. Rev. 1483 (1997) (applying systems analysis evaluation to proposed changes in bankruptcy law); Lynn M. LoPucki, Twerski and Cohen's Second Revolution: A Systems/Strategic Perspective, 94 Nw. U. L. Rev. 55 (1999) (critiquing medical informed consent proposal from perspective of systems analysis).

14 For an overview, see Florida Task Force, supra note 3, at 30-33.

15 See id. at 30 ("Like many states, Florida lacks a unified voting system for its 8.4 million voters."); supra note 4 and accompanying text (naming only nine states with uniform voting systems). 
five kinds of voting technologies in the November 2000 election; Iowa, with a smaller voting population than Florida, had six approved voting systems. ${ }^{16}$ Additional distinctions sometimes existed within larger categories; for example, Florida's sixty-seven counties used five voting technologies consisting of twelve different kinds of machines made by seven different manufacturers. ${ }^{17}$ To complete this inventory, a single Florida county, Union County, used its own old-fashioned paper ballots, all of which it counted by hand. ${ }^{18}$ Like other states, Florida constructed its election system out of a patchwork of different voting technologies-leaving the resulting assemblage a cobbled-together system with decidedly weaker and stronger elements.

This Part demonstrates that the Florida election system deployed technology in a fundamentally unequal manner. This finding casts harsh light on a central aspect of the U.S. Supreme Court's Bush opinion, which found that "[h]aving once granted the right to vote on equal terms, the State may not, by later arbitrary and disparate treatment, value one person's vote over that of another."19 This Part shows that Florida in fact had already granted the right to vote on unequal terms. The fashion in which Florida deployed its technology guaranteed unequal access to the franchise even before the first vote was cast.

The critical technological advantage some voters received over others was greater feedback about whether or not a ballot would be read correctly by a vote-counting machine. The design of the election infrastructure also had a racial and socioeconomic aspect; the Florida election system deployed voting technologies in a way that disproportionately harmed the chances of blacks and poor people to have their votes counted.

\section{A. "Edward Tufte Moments" and the Importance of Feedback}

The Florida election of November 2000 is especially fruitful as a case study because of the rich data sets available about it. Due to the partial and full county recounts, the report of the postelection Florida

16 Douglas W. Jones, Evaluating Voting Technology, Testimony Before the United States Civil Rights Commission (Jan. 11, 2001), at http://www.cs.uiowa.edu/ jones/voting/ uscrc.html [hereinafter Jones Testimony] (discussing technologies currently available for voting and outlining problems of each).

17 Division of Elections, Fla. Dept. of State, Voting Systems: Certified Voting Systems Used in Florida, at http://election.dos.state.fl.us/votemeth/cvs.shtml (last visited Feb. 14, 2002).

18 Florida Task Force, supra note 3, at 31; see also Mark Danner, The Road to Illegitimacy, N.Y. Rev. Books, Feb. 22, 2001, at 48 (describing Union County voting).

19 Bush v. Gore, 531 U.S. 98, 104-05 (2000) (per curiam). 
task force, ${ }^{20}$ the media-sponsored analyses, ${ }^{21}$ an investigation and report by the U.S. Commission on Civil Rights, ${ }^{22}$ and Florida's Freedom of Information Act,23 we probably know more about how Floridians did and did not vote than about the citizens of any other state in any other election in the United States.

This section examines the five Florida voting technologies and evaluates their performance according to their "residual rate." The residual rate indicates the number of discarded, invalid, and spoiled ballots, expressed as a percentage of the total vote. Some residual rate is inevitable because all voters do not wish to vote in all races. ${ }^{24}$ Yet the percentage of withheld votes in the same contest should be constant across all voting technologies. In other words, the same percentage of people should wish to withhold their vote independent of the technology they use. ${ }^{25}$ As a result, relative residual rates reveal much about the performance of different voting technologies: The best voting technology leaves the lowest rate of residual ballots, and the worst technology leaves the highest rate.

Edward Tufte, a pioneering design theorist, has argued that good graphical presentation of information can promote "the efficient communication of complex quantitative ideas." 26 In search of an "Edward Tufte moment," I have prepared two tables displaying data about the five voting technologies used in Florida in November 2000.

20 See Florida Task Force, supra note 3.

21 See, e.g., Martin Merzer et al., Miami Herald Report: Democracy Held Hostage (2001) [hereinafter Miami Herald Report]; Wash. Post Political Staff, Deadlock: The Inside Story of America's Closest Election (2001) [hereinafter Wash. Post Report].

22 U.S. Comm'n on Civil Rights, Voting Irregularities in Florida During the 2000 Presidential Election [hereinafter Civil Rights Comm'n], available at http://www.usccr.gov.

23 Fla. Stat. Ann. \$ 119 (West Supp. 1996); see Paul M. Schwartz \& Joel R. Reidenberg, Data Privacy Law 142-43 (1996) (describing Florida Public Records Law); Miami Herald Report, supra note 21, at 183 ("Under Florida's Sunshine Law, ballots are public documents, and the media and other organizations have the right to examine them.").

24 Caltech/MIT, Residual Votes, supra note 4, at 6-7.

25 Id.

26 Edward R. Tufte, The Visual Display of Quantitative Information 15 (1983); see also Edward R. Tufte, Envisioning Information (1990) (further developing Tufte's ideas about data representation). 
TABLE $\mathrm{A}^{27}$

FEEDBACK IN FLORIDA:

"Residual Rates" in Florida by Voting Technology

\begin{tabular}{|c|c|c|c|c|c|}
\hline & & & & RESIDI & $\begin{array}{l}\text { AL } \\
\text { TS }\end{array}$ \\
\hline VOTING SYSTEM & COUNTIES & $\begin{array}{l}\text { TOTAL VOTES } \\
\text { FOR } \\
\text { PRESIDENT }\end{array}$ & $\begin{array}{c}\text { ALL } \\
\text { BALLOTS }\end{array}$ & NUMBER & $\%$ \\
\hline Optical (precinct) & 26 & $2,055,755$ & $2,072,927$ & 17,172 & $0.83 \%$ \\
\hline Lever machine & 1 & 62,013 & 62,570 & 557 & $0.89 \%$ \\
\hline Punchcard (central) & $24 *$ & $3,571,616$ & $3,717,544$ & 145,928 & $3.93 \%$ \\
\hline Optical (central) & 15 & 264,873 & 280,813 & 15,940 & $5.68 \%$ \\
\hline Paper/hand & 1 & 3,826 & 4,084 & 258 & $6.32 \%$ \\
\hline TOTALS & 67 & $5,958,083$ & $6,137,938$ & 179,855 & $2.93 \%$ \\
\hline
\end{tabular}

Optical (precinct) means marked ballots are tabulated by machines at precinct level.

Optical (central) means marked ballots are tabulated by machine at a central elections office.

Punch card (central) means punch card ballots are tabulated by machine at a central elections office.

*Uncertified figures from three counties result in unofficial statewide totals.

: Includes all 10 presidential candidates on Florida ballot, plus valid write-ins.

*:*:-Includes absentee ballots, which tend to increase the number of residual ballots.

\section{TABLE B}

UNDERVOTES VERSUS OVERVOTES*

\begin{tabular}{|l|c|c|c|c|c|}
\hline & $\begin{array}{c}\text { NO. OF } \\
\text { VOTING SYSTEM }\end{array}$ & \multicolumn{4}{|c|}{ MIAMI HERALD TABULATIONS } \\
\hline & & UNDERVOTES & $\begin{array}{c}\text { Percentage } \\
\text { of Total }\end{array}$ & OVERVOTES & $\begin{array}{c}\text { Percentage } \\
\text { of Total }\end{array}$ \\
\hline Optical (precinct) & 26 & 5,686 & $37.15 \%$ & 9,620 & $62.85 \%$ \\
\hline Lever machine & 1 & 133 & $70.37 \%$ & 56 & $29.63 \%$ \\
\hline Punch card (central) & 24 & 54,217 & $38.43 \%$ & 86,878 & $61.57 \%$ \\
\hline Optical (central) & 15 & 1,050 & $6.74 \%$ & 14,520 & $93.26 \%$ \\
\hline Paper/hand & 1 & 25 & $11.79 \%$ & 187 & $88.21 \%$ \\
\hline Totals & $\mathbf{6 7}$ & $\mathbf{6 1 , 1 1 1}$ & $35.44 \%$ & $\mathbf{1 1 1 , 2 6 1}$ & $64.56 \%$ \\
\hline
\end{tabular}

*These results are drawn from the Miami-Herald, Knight Ridder and USA Today sponsored examination of the Florida undervotes. The examination itself was carried out by BDO Seidman, LLP, Certified Public Accountants. The results for all 67 Florida counties are posted online at http://www.miami.com/herald/special/news/flacount/docs/100973.htm (last visited April 23, 2002). Partial results from the study are also found in Miami Herald Report, supra note 21, at $222-301$.

From top to bottom, Table A runs from the best technology (lowest residual rate) to the worst (highest residual rate). In my judgment, this table leads to an "Edward Tufte moment" once one notices the large gap in performance between the first two voting technologies and the next three. I will explain each of the five technologies shortly;

27 See Florida Task Force, supra note 3, at 34-35. 
for now, it is important just to note the dramatic jump from the failure rate of less than $1 \%$ for the first two voting technologies, up to $3.93 \%$, then $5.68 \%$, and then $6.32 \%$ for the next three.

Table A also reveals that only a little more than two million of the roughly six million voters participating in the Florida election fell on the good side of the technology divide. Most people on the wrong side-over 3.7 million voters-had their votes processed with punchcard machines. Florida relied on this (bad) technology to handle many more ballots than any other single voting technology.

Table B concerns the difference between two types of residual ballots, undervotes and overvotes. An undervote is a ballot in which a counting machine found no voter choice for a particular office. ${ }^{28}$ While a voter intentionally may vote for no candidate in a particular office, an undervote may also be a false negative-where a machine reads no vote, but in fact a voter had expressed an intent. In contrast, an overvote is a ballot rejected by counting machines because it indicated more than one choice for an office. ${ }^{29}$ An overvote could be a valid vote if it reflected a false positive - that is, a machine incorrectly reads an extra vote by a voter who did not intend it.

In the dispute over the 2000 election, the distinction between undervotes and overvotes explored in Table B had crucial legal implications. According to the Florida Supreme Court, Al Gore made a successful showing at the trial level that sufficient "legal votes" existed among the undervotes to cast the outcome of the election in doubt. ${ }^{30}$ The Florida court decided to order examination by the county canvassing boards of all remaining undervotes. ${ }^{31}$ In contrast, the U.S. Supreme Court in Bush found omitting the overvotes from this examination a violation of the Equal Protection Clause. ${ }^{32}$ Invoking Edward Tufte's spirit once again, one can observe from Table B that

28 Wash. Post Report, supra note 21, at 53-54.

29 Id. In the case of an office where voters choose more than one candidate, such as some city council elections, an overvote is present when a ballot indicates more than the permitted number of choices.

30 Gore v. Harris, 772 So. 2d 1243, 1260-61 (Fla. 2000) (per curiam).

31 Id. at 1262.

32 Bush v. Gore, 531 U.S. 98, 109-10 (2000) (per curiam) ("The State has not shown that its procedures include the necessary safeguards. The problem, for instance, of the estimated 110,000 overvotes has not been addressed ...."). Ironically, this difference between the two courts may have proved moot had the manual recount ordered by the Florida Supreme Court been allowed to proceed. Judge Terry Lewis, the judge given responsibility over the aborted manual recount, reportedly had been considering an order to expand the recount to include overvotes as well as undervotes. Michael Isikoff, The Final Word?, Newsweek on the Web (Nov. 19, 2001), at http://www.stacks.msnbc.com/news.660124.asp. A ruling by Judge Lewis that overvotes be included in the total of legal votes might have caused another round of litigation in the Florida Supreme Court, however, as such an order would have exceeded the Florida court's limited order to count only undervotes. See 
different technologies used in the November 2000 election favored overvotes or undervotes to a greater or lesser degree. ${ }^{33}$

After examining this data, the question becomes: What distinguishes the two good voting technologies in Table $\mathrm{A}$ from the next three? The answer: the extent to which they provide feedback to the voter at the moment of exercising the franchise. James Beniger describes feedback as the result of a "two-way interaction" that allows the "reciprocal flow of information back to a controller," enabling "the comparison of inputs to goals." 34 The first two voting technologies used in Florida provided considerably more information to the voter about whether or not her ballot would be counted as she intended. These two technologies also had markedly superior residual rates.

We now can examine each of these technologies in turn, from best to worst, with this point about feedback in mind. ${ }^{35}$

The most successful technology in Florida in November 2000 was optical scanning equipment combined with precinct tabulation ("optical (precinct)"). Optical scanning technology is the same system used in the administration of standardized exams such as the Law School Admissions Test (LSAT). In Florida's electoral version of this technology, a voter used a pencil to blacken an oval or fill in an arrow. ${ }^{36}$ The critical difference between taking the LSAT and voting in Florida, however, concerned precinct tabulation. When a voter uses optical technology with precinct tabulation, a scanner is available at the voting place. A voter or a poll worker is able to feed a ballot into a scanner so that the voter can check it before surrendering it for final counting. ${ }^{37}$ In other words, before submitting a ballot, the voter finds out if a vote counting machine will be able to read it. As the Orlando Sentinel explained precinct tabulation, when a ballot cannot be read

the scanner rejects the ballot like a vending machine spitting out a wrinkled dollar bill, and the voter gets a second, or even third,

Gore, 772 So. $2 \mathrm{~d}$ at 1255 . Thus, it is impossible to predict the final outcome of such an order by Judge Lewis.

33 In this Section, I only intend to describe the relationship between different voting technologies and the creation of residual votes, whether overvotes or undervotes. I return later to the question of whether the decision to examine only undervotes can be said to disadvantage any set of voters unfairly. See infra notes 127-38 and accompanying text; infra notes $179-83$ and accompanying text.

34 James R. Beniger, The Control Revolution 8 (1986).

35 For another review of these five technologies, see Civil Rights Comm'n, supra note 22, at 90-98.

36 Florida Task Force, supra note 3, at 33.

$37 \mathrm{Id}$. ("Once the voter is finished completing the ballot, it is fed into a tabulating device at the precinct and the voter has the opportunity to correct any errors before leaving the precinct."). 
chance. In counties without precinct-based optical scanners, flawed ballots are discovered only after they've been trucked away to election headquarters to be counted. By that time, the voter is long gone and it's too late for corrections. ${ }^{38}$

The great advantage of optical (precinct) tabulation is that it provides feedback to the voter. With precinct tabulation, voters learn whether the choices that will be recorded from their ballots match their intended choices. For particularly strong proof of the importance of feedback, compare the residual rates of optical (precinct) voting to the rate in counties that used the same optical scanning machinery, but with central tabulation (optical (central)). In the latter approach, a voter also generally blackens an oval or fills in an arrow, but the ballot is taken without any indication of whether the vote will be tabulated by a scanner. ${ }^{39}$ In Florida, as Table A demonstrates, the same kind of technology used without feedback had a failure rate almost seven times greater $(5.68 / 0.83=6.84)$.

Furthermore, Table B shows that the different tabulation method yields a very different ratio of overvotes to undervotes. One could speculate that feedback might have played a role here too, because undervotes are more likely to be intentional abstentions by voters. Optical (precinct) voters with the benefit of feedback might have corrected erroneous overvotes, but this option was unavailable in optical (central) counties and the proportion of overvotes was much higher.

The second-best voting technology in Florida also demonstrates the importance of feedback to the voter. Old-fashioned mechanical lever machines had a $0.89 \%$ failure rate. Lever machines, which are no longer manufactured in the United States, provide feedback in the form of an "X" or similar mark that appears in the box next to a candidate's name once the voter has depressed the lever completely. This provides important visual reinforcement for the voter.

In addition, "interlocks" in lever machines mechanically prevent a voter from casting an overvote..$^{40}$ This is the surest form of feed-

38 Roger Roy \& David Damron, New System Fumbles Votes, Orlando Sentinel, May 6 , 2001, 2001 WL 9183081.

39 Florida Task Force, supra note 3, at 32-33 (explaining that optical (central) entails tabulation of ballots at central location). For a newspaper article that explains the importance of feedback to the voter, see Jackie Calmes, Key to Better Voting: Catching Errors at Their Source, Wall St. J., May 29, 2001, at A24.

40 Roy G. Saltman, U.S. Dep't of Commerce, Accuracy, Integrity, and Security in Computerized Vote-Tallying 28 (1988) (Nat'l Bureau of Standards, Special Publ'n No. 500-158). The last manufacturer of lever machines went out of business in 1982. Jackie Calmes, New Yorkers Won't Let Old Voting Machines Fade Away, Wall St. J., May 22, 2001, at A28. Businesses still exist that recondition the machines, however, and an individual who runs such a business claims that some lever machines in use in New York are seventy or even eighty years old. Id. 
back-physically stopping a voter from making a particular mistake. The only overvotes with lever machines in Florida thus came from paper absentee ballots, while undervotes could have been present in ballots cast either at the polling place or absentee, helping to explain the much larger percentage of undervotes for lever machines in Table B. A shortcoming of lever machines is that, while they produce a smaller residual rate overall, they create no audit trail; votes are recorded only on an odometer-like device in the back of the machine. ${ }^{41}$ As a result, only the absentee ballots could be examined during any recount. 42

As I have noted, voters who used the remaining three technologies were on the wrong side of the voting-technology divide. Punchcard balloting, the source of the 2000 election's infamous chads and dimpled ballots, came in third place on Table A. Punch-card balloting had a failure rate over four times worse than lever machines, the technology immediately on the other side of the divide $(3.93 / 0.89=4.41)$.

Punch-card balloting presents a relatively unfamiliar machine to the voter; indeed, the only widespread use of once-prevalent punch cards is in voting. ${ }^{43}$ Among the tasks required of a voter in a punchcard county were aligning the ballot correctly in the machine; punching holes in it with a stylus; and inspecting a ballot, which often has no candidate names printed on it.44 While a voter could inspect her punch-card ballot once it was out of the machine, given the unfamiliarity of punch cards today, this task is more than a little recondite.

The absence of feedback when completing such obscure tasks contributed to the high failure rate. Compared to the first two voting technologies, punch-card technology provided much less feedback to the voter. All punch-card balloting in Florida used central tabulation, which means that the ballots were taken from the voter and processed at a central location. ${ }^{45}$ No card readers were available at the precinct; a voter did not know whether her ballot would be read by a tabulation device. ${ }^{46}$ As Table B indicates, punch-card machines favored the crea-

41 Jones Testimony, supra note 16.

42 David Damron, System Counts Every Vote-And Then Some, Orlando Sentinel, Mar. 8, 2001, 2001 WL 9170327; see also Melissa E. Holsman, Media Check County's Absentee's Ballots, Stuart News/Port St. Lucie News, Jan. 5, 2001, LEXIS, News Library, STUNWS File (discussing difficulties of recount process in Martin County).

43 Jones Testimony, supra note 16.

44 Id. Depending on the kind of punch-card system used, moreover, the names might be placed in the machine's frame, but not found on each individual ballot.

45 Florida Task Force, supra note 3 , at 32.

46 Some overvotes, for example, were made when a voter attempted to punch holes for both a presidential candidate and his running mate, rather than one hole for the pair as required. Miami Herald Report, supra note 21, at 14. Other voters made an initial selection "and also used the write-in category to repeat the name of their candidates, apparently 
tion of overvotes; this may be in part because, when the ballot is in the machine, a voter can find it difficult to see if too many holes were punched or whether holes were punched in the right areas. ${ }^{47}$

Compounding the problem, wear and tear on machines sometimes meant that even if voters performed all these tasks correctly, they would not punch a clean hole. ${ }^{48}$ Even worse, investigations after the election revealed that some election officials were aware of these mechanical problems with particular punch-card machines and did not fix them. ${ }^{49}$ Between lack of feedback, unfamiliar machines, and in some cases faulty machines, punch-card technology presented a challenge to voters trying to cast their ballots.

In fourth and next-to-last place on Table $A$ is optical scanning (central), which I have already discussed above.50 With neither the feedback of precinct tabulation, nor the interlocks found in lever machines, nor the mechanical guidance that lever machines and even

believing that this represented a more emphatic vote" but instead invalidating their ballot with an overvote. Id.

47 Jones Testimony, supra note 16 . Note that while punch cards created dramatically more residual votes than optical (precinct) overall, see Table A, the breakdown between overvotes and undervotes in the two technologies was similar, see Table $B$. This may be explained in part by the particular nature of the mechanical problems experienced in punch-card machines-dimpled ballots, for example, are undervotes.

48 After the election, for example, the Miami Herald examined more than 250 voting machines used in the election in Palm Beach County. The review concluded that "the undervote problem there had more to do with bad equipment than voters." Miami Herald Report, supra note 21, at 66; see also David Kidwell \& Joseph Tanfani, Faulty Part May Have Voided Ballots, Miami Herald, Nov. 12, 2001, at 1A (finding faulty plastic template intended to guide voting stylus to correct location caused dimpled or hanging chads in nearly one out of ten test ballots).

49 Reporters from the Palm Beach Post found that $11.6 \%$ of election workers' 4867 test ballots in Palm Beach County recorded errors in the presidential race. Joel Engelhardt \& Scott McCabe, Poll Workers Ignored Flaws in Pre-Vote Machine Tests, Palm Beach Post, Dec. 9, 2001, 2001 WL 31097424 (reporting that poll workers punched test ballots and frequently found "[s]omehow, they didn't punch holes they were supposed to punch" or they left dimpled ballots and hanging chads). In all, 261 of the county's 531 polling places "had machines that registered errors on the tests conducted before the polls opened at 7 a.m." Id. Poll workers failed to seek replacement machines as required, and "voters cast ballots all day on those same machines." Id.; see also Kidwell \& Tanfani, supra note 48, at $1 \mathrm{~A}$.

With all the evidence of flawed voting machines in Florida, one is left to wonder about a curious aspect of Richard Posner's analysis of the Florida election. Posner correctly distinguished between (1) machine tabulation in counting ballots at the county level and (2) the voting machine itself. Posner, Deadlock, supra note 6, at 86-87. But he also asserted both that " $[t]$ here was nothing wrong with the tabulating machinery," id. at 87 , and that his statistical analysis of the Florida vote demonstrated that "[t]here is no indication that defects in the punchcard voting machines themselves are responsible for many undervotes or overvotes." Id. at 70 . Posner oversells the ability of regression analysis to prove the point; ample evidence from postelection reporting revealed highly defective voting machines causing voting errors.

50 See supra notes $37-39$ and accompanying text. 
punch-card technology can provide, voters made stray or extra marks easily, potentially invalidating their ballots. Evidence suggests that residual ballots also resulted, for example, if voters did not fill in an oval or arrow completely; if the supplied pen's ink was the wrong color or had insufficient carbon, which may have prevented certain kinds of scanners from reading ballots; 51 and, in some counties, if voters used their own pens or pencils rather than the supplied writing instrument required by some optical scanning machines. ${ }^{52}$ In addition, voters were not always supplied with erasers to correct their ballots and creases in ballots sometimes were read as overvotes. ${ }^{53}$

With all these problems, as Table A reveals, optical (central) voting technology performed miserably in the November 2000 electionit did even worse than punch-card voting technology, which received far more bad publicity. It also produced a larger percentage of overvotes than any of the other technologies. ${ }^{54}$

The fifth and worst-performing voting technology in Florida was the humble paper ballot, used only in small Union County (4084 ballots cast). As Mark Danner explained after the election:

Here, alone among Florida's sixty-seven counties, there is only paper, with the printed name of each candidate and to the right of each name a printed box meant to receive, in the form of a penciled cross or check or diagonal line, the mark of the voter's clearly stated will. 55

Although the number of votes concerned was small, one must conclude that this election system, with its $6.32 \%$ residual rate, performed poorly in Florida. In Union County, as in the punch-card (central) and optical scanning (central) counties, the individual received scant information about whether her vote would be correctly understood before she surrendered her ballot. With this system, as with optical (central), many more overvotes than undervotes were created, also presumably because of a lack of feedback. Moreover, a recount would have little impact in Union County, because humans individually examined every paper ballot in Union County already on election day. ${ }^{56}$ And as we shall see shortly, nontechnological factors may also

51 David Damron, Voting-Machine Glitches Hurt Gore in Seminole, Orlando Sentinel, Feb. 15, 2001, 2001 WL 9165776.

52 Martin Merzer, Optical Scanning Isn't Perfect, Miami Herald, Apr. 6, 2001, at 1.

53 Roger Roy \& David Damron, Small Counties Wasted More than 1,700 Votes, Orlando Sentinel, Jan. 28, 2001, 2001 WL 9161837.

54 See Table B. To the extent that overvotes are more likely than undervotes to be cast mistakenly, this suggests that optical (central) might have produced an even larger proportion of erroneous residual ballots than punch-card technology.

55 Danner, supra note 18 , at 48.

56 As Danner noted: 
have played a role in Union County's abysmal residual rate in the 2000 presidential election. 57

In summary, voting methods in Florida that provided feedback were much more successful than those that did not. As a result of differences among voting technologies, equal access to voting did not exist in Florida. Specifically, the Florida election system failed to provide an equal opportunity to have one's ballot counted. While technology was at the center of this inequality, it also had other features, and it is to this aspect of the Florida election that I now turn.

\section{B. Election Ecologies}

I have concentrated thus far on tracing the connection between residual rates and different voting technologies. Yet I do not wish to adopt a stance of pure technological determinism; voting technologies are always embedded in social and political environments that shape technological performance. ${ }^{58}$ Systems analysis concerns itself with these nontechnological aspects of voting environments as well as the machinery used. Florida had not only good and bad technology, but good and bad voting environments.

This mixture of social and political factors combined with a given voting technology should be seen as creating an "election ecology." These overall environments for voting in the November 2000 election in Florida differed sometimes not only from county to county, but also from precinct to precinct. As this Section demonstrates, election ecologies interact with racial and socioeconomic factors.

\section{Election Technology's Negative Impact on Racial Minorities and the Poor in Florida}

First, some initial statistics: Black voters, who constituted an estimated fifteen percent of Florida voters in 2000, made up the majority

These ballots had already been counted by hand-they were only counted by hand-and the sort of mistakes these double votes represented, unlike many of those on the punch cards in Palm Beach and Broward and Duval Counties, presented an ambiguity of intention that no human counter could penetrate; these were the final errors, those that had to be placed squarely on the side of the uncorrectable.

Danner, supra note 18 , at 48.

57 See infra Part I.B.1.

58 See John Seely Brown \& Paul Duguid, The Social Life of Information 70-77 (2000) (discussing significance of information technology and its social and institutional contexts); Bonnie A. Nardi \& Vicki L. O'Day, Information Ecologies 49-75 (1999) (same). The latter authors "define an information ecology to be a system of people, practices, values, and technologies in a particular local environment." Id. at 49. 
of voters in 463 of the state's 5885 precincts. ${ }^{59}$ A joint study by the Miami Herald and USA Today found that voters in these majorityblack precincts were nearly four times more likely to have their votes for president found invalid than voters in majority-white precincts. ${ }^{60}$ Eighty-two percent of Florida's majority-black precincts had discard rates above the statewide average, as opposed to forty-one percent of majority-white precincts with above-average rates. ${ }^{61}$ Eighty-three of the one hundred precincts with the highest number of disqualified ballots had black majorities. ${ }^{62}$ Fifty-seven of these precincts-and thirteen of the fifteen precincts with the highest percentage of residual ballots-were in Duval County, which falls in the punch-card (central) category. ${ }^{63}$

This Article began by noting the particularly stark contrast along racial lines between Leon County, which had the lowest percentage of residual ballots in Florida for the November 2000 election, and adjoining Gadsden County, which had the highest. ${ }^{64}$ Leon County, situated in a prosperous area in Florida, hosts the state capital and two state universities. ${ }^{65}$ Just on the other side of the Ochlockonee River, Gadsden County is located in a poor rural area and is the only majorityblack county in Florida. ${ }^{66}$ Leon County has optical (precinct) technology, while Gadsden County has optical (central) technology.

\section{TABLE $\mathrm{C}^{67}$}

Leon County and Gadsden County Spollage Rates

\begin{tabular}{|l|c|c|c|c|c|}
\hline \multicolumn{3}{|c|}{} & \multicolumn{2}{c|}{$\begin{array}{c}\text { RESIDUAL } \\
\text { BALLOTS }\end{array}$} \\
\hline COUNTY & VOTING SYSTEM & $\begin{array}{c}\text { TOTAL } \\
\text { PRESIDENT* }\end{array}$ & $\begin{array}{c}\text { ALL } \\
\text { BALLOTS:* }\end{array}$ & NUMBER & $\%$ \\
\hline Leon & Optical (precinct) & 103,196 & 103,377 & 181 & $0.18 \%$ \\
\hline Gadsden & Optical (central) & 14,727 & 16,812 & 2,085 & $12.40 \%$ \\
\hline
\end{tabular}

*Includes all 10 presidential candidates on Florida ballot, plus valid write-ins.

*: Includes absentee ballots, which tend to increase the number of residual ballots.

59 Andres Viglucci et al., Blacks' Votes Were Discarded at Higher Rates, Analysis Shows, Miami Herald, Dec. 28, 2000, at 1A.

60 Id.; Laura Parker \& Peter Eisler, Ballots in Black Fla. Precincts Invalidated More, USA Today, Apr. 6, 2001, at 1A.

61 Miami Herald Report, supra note 21, at 115.

62 Parker \& Eisler, supra note 60 , at $1 \mathrm{~A}$.

63 Id.

64 Supra notes 1-2 and accompanying text; Bob Drogin, 2 Florida Counties Show Election Day's Inequities, L.A. Times, Mar. 12, 2001, at A1.

65 Drogin, supra note 64, at A1.

66 Id.

67 See Florida Task Force, supra note 3, at 33. 
Turning to Edward Tufte for the last time, I set out the relevant information regarding residual ballots in these two counties in Table C. As this table demonstrates, the voters in the only majority-black county in the state were over sixty-eight times more likely to have their votes left uncounted than those in the adjoining majority-white county $(12.4 / 0.18=68.89)$. Expressed as a percentage, voters in Gadsden County faced a $6889 \%$ greater failure rate than those in Leon County.

How much of this failure rate should we attribute to technology? As I have suggested, an election ecology is constituted only partly by technology. ${ }^{68}$ Thus, Table $\mathrm{C}$ may risk misinterpretation; it is not intended to show "hard" technological determinism at work in Florida's 2000 elections, but to illustrate that technology plays an important role in overall election ecologies that harm African Americans.

This role was further demonstrated in reports by Allan J. Lichtman, an expert on voting statistics retained by the U.S. Commission on Civil Rights, who conducted a series of statistical analyses of ballot-rejection rates for the Commission's investigation of the Florida election. ${ }^{69}$ First, he noted that blacks were slightly more likely than whites to live in counties with inferior voting technologies. ${ }^{70} \mathrm{His}$ analysis also found that "the type of technology used accounts for some of the relationship between race and the rates at which ballots are rejected."71 In other words, an already strong correlation between race and ballot rejection proved even stronger in counties with technology on the wrong side of the voting-technology divide.

At the same time, only part of Florida's failure to count black votes can be attributed to the technology divide alone. In counties with superior optical (precinct) technology, the correlation between race and ballot spoilage declined, but did not vanish. ${ }^{72}$ Lichtman also discovered that a link between race and ballot-rejection rate remains if one controls at the county level for differences in eduction, income,

68 For discussion of some other problematic aspects of Florida's election ecologies, see infra Part I.B.2.

69 See Allan J. Lichtman, Report on the Racial Impact of the Rejection of Ballots Cast in the 2000 Presidential Election in the State of Florida [hereinafter Lichtman Main Report], in Civil Rights Comm'n, supra note 22, app. VII; Allan J. Lichtman, Supplemental Report on the Racial Impact of the Rejection of Ballots Cast in Florida's 2000 Presidential Election [hereinafter Lichtman Supplemental Report], in Civil Rights Comm'n, supra note 22, app. X.

70 See Lichtman Main Report, supra note 69, at 4 ("About 70 percent of black registrants resided in counties using technology with the highest ballot-rejection rates-punch cards and optical scanning systems recorded centrally-compared to 64 percent of nonblack registrants.").

71 Id. at 5.

72 Id. at $4-5$. 
poverty, and literacy. ${ }^{73}$ The lesson of Lichtman's statistical analysis is sobering: The strongest predictor for ballot-rejection rates in Florida's 2000 election was the racial composition of the county. Other studies have also concluded that optical (precinct) technology helped all voters, regardless of race, when it was available. ${ }^{74}$ Technology exacerbates the underlying racial disparity, and closing the voting-technology divide would reduce it - but would not eliminate it. ${ }^{75}$

Independent of race, a correlation also exists between the distribution of voting technology and the relative wealth of a Florida county. ${ }^{76}$ Poorer counties were especially likely to centralize counting of ballots rather than use precinct tabulation. ${ }^{77}$ Precinct tabulation is costly: For example, a county would need to spend as much as $\$ 5000$ per precinct for a scanner in each voting place. ${ }^{78}$ Florida provides almost no financial assistance to counties to run elections, ${ }^{79}$ so the tendency of poorer counties not to use precinct tabulation is hardly surprising. The differences played out in residual rates. A Miami Herald analysis of uncounted ballots found, "ballots in precincts with

73 Lichtman Supplemental Report, supra note 69, at 8-11. Lichtman also presents evidence that the number of first-time voters fails to explain racial disparities in ballot spoilage rates. Id. at 11; see also Florida Task Force, supra note 3, at 37-38 ("The differences in error rates among various kinds of voting systems are much too high to be accounted for solely by uneducated, uninformed or disinterested voters.").

74 Compare, Viglucci et al., supra note 59, at $1 \mathrm{~A}$ ("Discard rates for all groups, including blacks, were minimal in precincts where electronic machines scan fill-in-the-oval ballots and immediately alert voters to botched ballots so they can correct them."); see also Caltech/MIT Voting Technology Project, Voting: What Is, What Could Be 22 (July 2001) [hereinafter Caltech/MIT, What Could Be] (finding patterns in technology failure rates hold up when controlling for various factors including race), available at http:// web.mit.edu/newsoffice/hr/2001/VTP_report_all.pdf.

75 See Lichtman Main Report, supra note 69, at 13 (concluding that improvement of technology would help address problem of higher residual rate for black voters, but noting that "[t]echnology alone is not the answer to racial disparities in ballot rejection").

76 Civil Rights Comm'n, supra note 22, at 97; Miami Herald Report, supra note 21, at 116. Literacy also plays a role in shaping an election ecology: A lack of preelection votereducation programs, incorrect voting instructions, and an absence of language assistance at polling stations cause additional stress on those with poor reading skills who attempt to vote. In his own analysis of the data regarding overvotes and undervotes in Florida, Posner found literacy to be one of the strongest variables. See Posner, Deadlock, supra note 6, at 74-78. Perhaps the most extreme example is Union County, an impoverished county with a high rate of illiteracy and the only county to use paper ballots for the 2000 election. See Danner, supra note 18 , at $48-49$; supra notes $55-57$. Not surprisingly, paper ballots performed particularly poorly in this environment.

77 See Posner, Deadlock, supra note 6, at 90-91.

78 Florida Task Force, supra note 3, at 33; see Posner, Deadlock, supra note 6, at 90 ("Poorer counties are more likely to centralize counting because it is more economical than counting at each precinct and then merging the results; smaller staffs and, especially fewer tabulating machines are required.").

79 Civil Rights Comm'n, supra note 22, at 47-48. 
high poverty were discarded at a rate nearly double that of better-off precincts." 80

\section{Election Ecologies and the Implementation of Technology}

In addition to the technology used, the election ecology of a county or precinct depends on the manner in which that technology is implemented. A complete systems analysis must consider these factors as well.

As an example of a good election ecology (albeit with one troubling aspect), return to Leon County and its low rate of residual ballots. ${ }^{81}$ More was behind this excellent result than technology; Leon County had an unusually active program of voter education in place for the 2000 election. ${ }^{82}$ Creating such a program posed a challenge, however, because Florida did not provide any state funds to counties for voter education. 83

The elections commissioner in Leon County, disturbed by this lack of state funds for voter education, collected donations from wealthy individuals in order to film an advertisement on voting procedures. ${ }^{84} \mathrm{He}$ also persuaded the local cable franchise to run the how-to advertisement for half price before the election. ${ }^{85}$ As the Los Angeles Times summarized, "[n]o other Florida county took such pains to educate voters." 86 Despite the good results in Leon County, however, this solicitation of donations by a state election official is a troubling precedent. Over time, such practices inevitably will raise questions about the integrity of the election process. ${ }^{87}$

Shifting focus now to a county with bad results, we can consider the election ecology of Duval County. First, this county managed to publish a sample ballot in newspapers that contained incorrect instructions; when these instructions were followed, an invalid vote re-

\footnotetext{
80 Viglucci et al., supra note 59.

81 See supra Table C; supra notes 64-66 and accompanying text.

82 For example, Leon County mailed sample ballots to each voter and sent detailed voting instructions to newly registered voters. Drogin, supra note 64.

83 U.S. Civil Rights Comm'n, supra note 22, at $47-48$ (citing testimony of Director of Florida's Division of Elections).

84 Drogin, supra note 64.

85 Id.

86 Id.

87 The national debate about campaign finance reform and the disproportionate influence that rich donors can obtain from elected politicians echoes the concerns that arise when election officials are obligated to pass the hat in order to run elections. For an introduction to the complexities of campaign finance reform, see generally Campaign Finance Reform: A Sourcebook (Anthony Corrado et al. eds., 1997); Samuel Issacharoff, Pamela S. Karlan, \& Richard H. Pildes, The Law of Democracy: Legal Structure of the Political Process 449-545 ( $2 \mathrm{~d}$ ed. 2001).
} 
sulted. ${ }^{88}$ Moreover, while the actual ballot in Duval County contained correct instructions, the ballot design itself was confusing. Candidates for president spilled over two pages of the ballot, but only one selection could validly be made. ${ }^{89}$ If a voter expressed a preference in this race for a candidate on each page of the ballot, her vote for president would be void.

Other counties in Florida had poor election ecologies due to ballot design failures and other issues. One example is the infamous butterfly ballot of Palm Beach County. This ballot split candidates into two columns and placed the punch hole for Reform Party nominee Pat Buchanan between those of the Republican and Democratic candidates, even though these latter two were listed side-by-side in the column on the left.90 The ballot layout violated then-existing design rules specified in the Florida election code. ${ }^{91}$ Similarly, the failure of election officials to correct problems uncovered by test ballots can be seen as a failure of election ecology in some Florida counties. ${ }^{92}$

Perhaps the most controversial problem of election ecology originated when Florida hired a private company, ChoicePoint Data, to remove ineligible voters from the election rolls. ${ }^{93}$ The company collected and processed data from other states about ex-felons and turned the information over to the Division of Elections, which sent the data to county officials. Each county decided what, if anything, to do with the information. ${ }^{94}$

88 Miami Herald Report, supra note 21 , at 115-16.

89 Id.

90 For a photo of this notorious ballot, see Miami Herald Report, supra note 21, at photo insert after 154 . Palm Beach also had mechanical problems with voting machines. As the Miami Herald summarized, "It turned out that voters in [Palm Beach County] were handicapped by faulty machines and a confusing ballot design . . . and nothing short of electoral chaos resulted." Id. at 85 . Other Florida counties also split presidential candidates across two columns. Jeff Kunerth \& Jim Leusner, Some Had 1 From 'Column A,' 1 From 'Column B,' Orlando Sentinel, Jan. 28, 2001, available at 2001 WL 9161833.

91 See Fla. Stat. chs. 101.191 (repealed 2002), 101.28(1) (repealed 2002). For discussion of the errors, see Ronald Dworkin, The Phantom Poll Booth, N.Y. Rev. Books, Dec. 21, 2000 , at 96.

92 See supra note 49 and accompanying text.

93 The story originally was uncovered by Gregory Palast. See Gregory Palast, Florida's 'Disappeared Voters': Disfranchised by the GOP, The Nation, Feb. 5, 2001, at 20 [hereinafter Palast, Disappeared]; Gregory Palast, Florida's Flawed 'Voter-Cleansing' Program, Salon, Dec. 4, 2000, at http://www.salon.com/politics/feature/2000/12/04/voter_file/ index.html [hereinafter Palast, Voter-Cleansing]. For other accounts of the voter purge, see Bob Herbert, Keep Them Out!, N.Y. Times, Dec. 7, 2000, at A39; Linda Kleindienst, Purge of 'Felons' on Voter List Under Fire, Orlando Sentinel, Feb. 23, 2001, at B1, 2001 WL 9167458; Robert E. Pierre, Botched Name Purge Denied Some the Right to Vote, Wash. Post, May 31, 2001, at A1.

94 See Palast, Voter-Cleansing, supra note 93. 
Mistakes by ChoicePoint and the Florida Secretary of State caused a number of flaws in this process. For example, while Florida felons are not permitted to vote without completing a complicated clemency process, Florida allows felons convicted in other states to vote in Florida if those other states automatically restore voting rights. ${ }^{95}$ Yet the Florida Department of State instructed ChoicePoint to collect data even from states that automatically restore voting rights to felons. ${ }^{96}$ This aspect of the purge violated existing Florida case law regarding civil rights restoration. ${ }^{97}$ Other errors in the electronic purge stemmed from a lack of data cross-checking by ChoicePoint, which, in its defense, now argues that the Florida Secretary of State's office ordered it to sweep broadly. 98

The impact of the electronic purge was unmistakable: Eligible voters were removed in counties when local election officials decided to use the purge results. ${ }^{99}$ The U.S. Civil Rights Commission deter-

95 After the election, Florida officials adjusted their practices and no longer place the burden on ex-felons from these other states to prove that their voting rights have been restored-although one official said that Florida, in adjusting its practices, was trying merely to "correct any misunderstanding" about the previous policy. David Ruppe, Florida Changes Policy on Ex-Felons' Voting Rights, abcnews.com, Mar. 26, 2001, at http:// more.abcnews.go.com/sections/us/dailynews/floridafelonvote_010321.html. After the election, Janet Keels, coordinator of Florida's Office of Executive Clemency, claimed that elections officers were confused by her statement that felons without written proof of rights restoration "would be required to make application for restoration of civil rights in the state of Florida." Maya Bell, Ex-Cons Struggle to Regain Rights, Orlando Sentinel, Mar. 12, 2001, 2001 WL 9171225. She said that she had meant to explain that those convicted in other states should inquire about their status in Florida, rather than suggest that state elections officials were to forbid them from voting. Id.

96 Palast, Disappeared, supra note 93, at 21.

97 Doyle v. Fla. Dept. of State, 748 So. 2d 353, 355-56 (Fla. Ct. App. 1999) (holding that, if sister state had not suspended person's civil rights following violation of law in that state, there was no need for these rights to be "restored" in Florida, regardless of whether violation in question would have led to suspension of rights had it occurred in Florida); Schlenther v. Fla. Dept. of State, 743 So. 2d 536, 537 (Fla. Ct. App. 1998) (finding that restoration of civil rights in another state, Connecticut, was entitled to full faith and credit in Florida).

98 Following an investigation, the Los Angeles Times reported:

[ChoicePoint] proposed cross-checking voter lists with an array of federal, state and county records, from convictions to address changes. The company also urged searching only for voters with the same exact name as a felon. But Florida officials told [ChoicePoint] to include names that were merely similar or had matching birth dates or Social Security numbers. An $80 \%$ match was sufficient, state officials said.

Lisa Getter, Florida Net Too Wide in Purge of Voter Rolls, L.A. Times, May 21, 2001, at A1.

99 Conversely, ineligible ex-felons were sometimes able to vote in those Florida counties that decided not to use the purge results. Miami Herald Report, supra note 21, at 10406. 
mined that state officials failed to safeguard these voters when setting policies for the purges. ${ }^{100}$

As a final observation on the election ecologies of Florida, it is important to note that differences in the implementation of technologies, like differences in the technologies themselves, interacted with racial and socioeconomic factors. The flawed felon purge, for example, had a disproportionate impact on minority voters. ${ }^{101}$ The cumulative effect of these mutually reinforcing inequalities-of technology and its implementation-assured that Florida did not grant the right to vote on equal terms. Rather, unequal access was built into the state's overall election ecology.

II.

Of Technological Subsidiarity and Technological Fallibility: The Florida Supreme Court's Gore Decision AND the U.S. Supreme Court's Bush Dissent

As this Article has shown, the Florida election system did not perform well in November 2000. This poor performance, combined with the closeness of the election and the pivotal status of Florida's electoral votes, led to the postelection avalanche of litigation in federal and state courts. On December 8 , as the national election night entered its fifth week, the Florida Supreme Court issued an opinion in Gore v. Harris that was largely favorable to Vice President Al Gore. ${ }^{102}$ The next day, with C-SPAN broadcasting live scenes of canvassing boards counting ballots, the U.S. Supreme Court issued a stay of the Florida court's opinion by a 5-4 vote. ${ }^{103}$ Nine days after issuing this stay and thirty-four hours after hearing oral argument, the U.S. Supreme Court delivered another 5-4 decision; this ruling ended the counting of ballots by Florida officials and effectively ended the fight over the 2000 presidential election as well. ${ }^{104}$

100 Civil Rights Comm'n, supra note 22, at 110 ("There were no clear guidelines from the governor, the secretary of state, or the director of the Division of Elections to subordinates to employ list maintenance strategies that would protect eligible voters, particularly historically disenfranchised populations, from being wrongfully removed from the votingregistration rolls.").

101 Id. (finding that Florida's purge "resulted in a disproportionate number of eligible African American voters being removed from the voter registration rolls in error"). For instance, in Miami-Dade, over $65 \%$ of those on the purge list were African-Americans, who represent only $20.4 \%$ of the county's population. Whites, in contrast, make up $77.6 \%$ of the county's population, but only $17.6 \%$ of those on the purge list. Id. at 23 .

102772 So. 2d 1243 (Fla. 2000) (per curiam).

103 Bush v. Gore, 531 U.S. 1046 (2000) (granting stay).

104 Bush v. Gore, 531 U.S. 98 (2000) (per curiam). 
In this Part, I explain the Florida Supreme Court's Gore decision in terms of its distinct epistemology of technology. I will also relate this belief system to the views of the Justices who dissented from the U.S. Supreme Court's Bush opinion.

\section{A. The Florida Gore Decision}

\section{The Majority Opinion}

In Gore, the Florida Supreme Court, by a 4-3 vote, ordered that the final statewide tally include both (1) partial vote totals from Miami-Dade County, which had halted its counting of ballots during the initial "protest" phase of the postelection period, and (2) late vote totals from Palm Beach County, which had sent its recount results to Florida Secretary of State Katherine Harris a few hours late. ${ }^{105}$ The court also ordered a manual count to be conducted in all counties where an unexamined undervote existed; ${ }^{106}$ following the canvassing board's certification of victory for Bush by 537 votes, approximately 60,000 undervotes and 110,000 overvotes were still distributed among Florida's counties. ${ }^{107}$ The court denied Gore's other challenges, relating to certification decisions in Nassau County and Palm Beach County. ${ }^{108}$

Gore's legal challenges during both the protest and contest phases $^{109}$ concentrated only on the undervotes-and only those in selected counties. As an advisor to Gore later explained the decision not to request a statewide counting of both undervotes and overvotes, "It was discussed but the consensus was that we couldn't get it. There was a feeling the courts wouldn't give it to us."110 This tactic of concentrating on undervotes had at least short-term success; the Florida Supreme Court ordered a statewide manual examination of all remaining undervotes. ${ }^{111}$ That decision specified that an undervote was to be counted as a "legal vote" whenever, in the language of the Florida election code, "there is "clear indication of the intent of the

105772 So. $2 d$ at $1260-62$.

106 Id. at 1261-62.

107 See supra Table B. Undervotes and overvotes are defined supra notes 28-29 and accompanying text.

108 Gore, 772 So. $2 d$ at 1248.

109 A candidate or a voter may "protest" a county's returns before it certifies the results or within five days of the election, whichever is later. Fla. Stat. ch. 102.166 (1993). Afterwards, "[a] candidate whose protest is denied or who does not file a protest can still challenge the certified election result by bringing an action in state court to 'contest' the certification." Kramer, supra note 6, at 108; see Fla. Stat. ch. 102.168 (1993).

110 Martin Merzer, 'Overvotes' Leaned to Gore, Miami Herald, May 11, 2001, at A1 (quoting Gore aide Doug Hattaway).

111 Gore, 772 So. 2d at 1261-62. 
voter." "112 The Florida court assigned responsibility for statewide undervote tabulation to Circuit Court Judge Terry P. Lewis, who promptly sent faxes to the local judges supervising examination of the undervotes in order to develop uniform procedures. ${ }^{113}$

As a result of these strategic decisions by the Gore campaign, the Florida Supreme Court did not entertain any broader claim protesting inequality under the Equal Protection Clause or the Voting Rights Act. 114 Instead, the court heard a case under the Florida election code in which Gore alleged that the undervotes in certain counties included "a number of legal votes sufficient to change or place in doubt the result of the election." 115 The Florida Supreme Court decided that, in light of the closeness of the election, humans were obligated to review all 60,000 undervotes. These ballots might contain false negatives, that is, a machine's determination of "no vote" for president where a human eye would identify voter intent.

\section{Of Technological Subsidiarity and Technological Fallibility}

Here, in a nutshell, are the two critical elements of the Florida Gore court's approach to election technology. Its first belief can be termed technological subsidiarity; in this view, machines are only ancillary to human decisionmaking and the fulfillment of human goals. The truth of decision-by-machine must ultimately be verified by human scrutiny. The second belief is technological fallibility; the court articulated specific suspicions regarding the terms on which the Florida election system had provided access to voting technology and expressed concerns about unequal access.

Like the Florida court, we begin with technological subsidiarity. Recall how Thomas Hughes defined technology as "the effort to organize the world for problem solving so that goods and services can be invented, developed, produced, and used."116 The task for Florida on November 7, 2000 was to elect political representatives, and it had turned to technology to carry out this work. Ballots were used for

112 Id. at 1257 (quoting Fla. Stat. ch. 101.5614(5) (Supp. 1994)). The recourse to the "clear intent of the voter" standard would have fateful consequences for the U.S. Supreme Court's review of this decision. See Bush v. Gore, 531 U.S. 98, 105-08 (2000) (per curiam).

113 See Gore v. Harris, 773 So. 2d 542, 534 n.23 (Fla. 2000) (Pariente, J., concurring) ("I remain confident that if the recount had continued in a timely manner, any obvious disparity in counting votes would have been reviewed by Judge Terry Lewis whose initial order on December 8,2000 , demonstrated an orderly and objective approach to the recount procedure."); cf. supra note 32 (discussing reports that Judge Lewis considered extending recount to overvotes).

114 See infra Part IV.A.3 (proposing litigation of such claims as response to voting-technology divide).

115 Gore v. Harris, 772 So. 2d 1243, 1247 (Fla. 2000) (per curiam).

116 Hughes, supra note 11, at 6 (emphasis removed). 
recording votes, and machines for counting votes. Yet, as the Florida court observed in a related case, "[O]ur society has not yet gone so far as to place blind faith in machines. In almost all endeavors, including elections, humans routinely correct the errors of machines."117

The Gore court saw machines and the other elements of election technology as means to an end that involved human decisionmaking; technology was only ancillary to the task at hand of assessing the will of the voters. The vote counting machines had left "residual" ballots. The essential principle, according to the Florida Supreme Court, is that "the outcomes of elections be determined by the will of the voters." 118 As a result of Gore's showing at the trial level during the contest phase, the undervotes were now "evidence in the election contest," and only if humans examined them could "a meaningful and final determination in this election contest be made."119

The Florida court bolstered its belief in the subsidiary nature of technology by drawing on applicable language from the state election code and the relevant legislative history. It concluded, "The clear message from this legislative policy is that every citizen's vote be counted whenever possible, whether in an election for a local commissioner or an election for President of the United States." 120 This imperative served the voter's interest in both participation and "voice" in government. ${ }^{121}$ In other words, representative government functions through the self-governance of those who own government-the voters. ${ }^{122}$ This idea is as old as the American republic. In The Rights of Man, for example, Thomas Paine argued in favor of "the representative system" in these terms: "Every man is a proprietor in government and considers it a necessary part of his business to understand." 123

The Florida Supreme Court complemented an articulation of its belief in technology's subsidiary status with an expression of specific suspicions regarding technological fallibility in the case before it. While this Article has identified and analyzed the five election tech-

117 Palm Beach County Canvassing Bd. v. Harris, 772 So. 2d 1273, 1284 (Fla. 2000).

118 Gore, 772 So. 2d at 1253.

119 Id. at 1261.

120 Id. at 1254; see Kramer, supra note 6, at 105, 113-14 (noting long history of Florida judicial decisions about fundamental nature of right to vote in that state).

121 See infra Part IV.A.1 (discussing these interests in electoral equality).

122 Gore, 772 So. 2d at 1256; see also Delahunt v. Johnston, 671 N.E.2d 1241, 1243 (Mass. 1996) ("The voters are the owners of the government, and our rule that we seek to discern the voter's intention and to give it effect reflects the proper relation between government and those to whom it is responsible.").

123 Thomas Paine, The Rights of Man, in Two Classics of the French Revolution 267, 419 (Anchor Books 1989). 
nologies Florida used in 2000 , the court perceived only two. It pointed to the different comparative rates of technological failure between (1) the optical (precinct) counties (which it did not distinguish from optical (central) counties) and (2) the punch-card (central) counties. ${ }^{124}$ Although its view was truncated, the Florida court captured the essential unfairness in the Florida election. The opinion observed that some counties "implement systems (such as the optical scanner) where the margins of error . . . are consistent with accountability in our democratic process." 125 In contrast, other counties depended on punch-card systems that "failed to record legal votes" at rates "so great to suggest that it is necessary to reevaluate utilization of the mechanisms employed as a viable system."126

The Gore court correctly realized that the different failure rates of optical scanner machines and punch-card voting machines raise basic issues of democratic fairness. It grasped the basic outline of the Florida voting-technology divide and the built-in unfairness in the election system. Its focus was only on the disparity between optical (precinct) and punch-card technology; as Table A demonstrated, two million Floridians voted with the former, highly accurate technology (and its $0.83 \%$ residual rate), and 3.7 million voters used the latter, inaccurate technology (and its 3.93\% residual rate).

The Florida court did not, however, have a full grasp of the implications of the different technologies in Florida for the creation of overvotes and undervotes. Indeed, a complete numerical breakdown of residual ballots by voting technology was not even possible until a media-sponsored county-by-county examination of residual ballots was completed in May 2001, approximately five months after the opinion was issued.127 With the benefit of this data, it is possible to examine the implications of the decision to count undervotes but not overvotes.

For four out of five technologies, this decision made no difference. Part I.A demonstrated that a recount would not have helped or hurt any voters in the counties with lever machines or paper ballots. ${ }^{128}$ In optical (precinct) systems and punch-card systems, the numerical breakdown between undervotes and overvotes was quite similar. The

124 Gore, 772 So. $2 \mathrm{~d}$ at 1261 n. 20 .

125 Id.

126 Id.

127 See supra Part I.A; supra Table A (reporting figures that only became available long after close of litigation).

128 The lever machines left no audit trail. Some voters in the county that used lever machines had made use of absentee ballots, but these had already been manually counted before Election Day. As for voters with paper ballots, their ballots were all counted by hand. See supra Part I.A. 
most relevant difference here is that many more overall residual ballots were created with punch-card machines, a technology that fell on the wrong side of Florida's voting-technology divide. In counties that used either technology, the decision to count only undervotes caused no disadvantage relative to voters using other technologies.

Where the Gore court's decision to count only undervotes did cause some unfairness for voters was in optical (central) counties. These voters used technology that heavily favored the creation of overvotes (the breakdown, indicated in Table B, is $6.74 \%$ undervotes versus $93.26 \%$ overvotes). Hence, we are left with a messy result of the Gore court's incomplete vision of technology: The decision to count only undervotes meant that one of the groups most harmed by the voting-technology divide in Florida would receive less assistance than other voters.

The Gore court correctly found that technology in the Florida election was fallible at different rates. Having identified such technological fallibility, the court's belief in the subsidiarity of technology in elections demanded a response. Its response was to order human examination of all undervotes to limit these disparities in technological performance. This incomplete response, however, failed to assist fully those voters in counties that used optical (central) technology. As I have indicated, however, the Gore court, and for that matter everyone in Florida, lacked access to the data that indicated this difficulty. In the next section, I will also point to certain other limitations that this court faced in its remedial role in the aftermath of the November 2000 election.

\section{The Overvotes, the Florida Dissenters, and the Judicial Role in Election Systems}

In ordering only undervotes to be counted, the Florida Supreme Court responded to two limitations on its role within the election system. First, because of the Gore campaign's litigation strategy, the dispute before the court concerned undervotes alone-specifically whether "legal votes" were present in this category of residual votes. ${ }^{129}$ The lack of any legal showing about the possibility of valid votes among the overvotes limited the kind of relief that the Florida court could order. ${ }^{130}$

129 See supra note 110 and accompanying text (noting that Gore campaign's litigation strategy was limited to undervotes); Gore, 772 So. 2d at 1256-57 (discussing elements of legal vote).

130 Bush v. Gore, 531 U.S. 98, 135 (2000) (Souter, J., dissenting) (noting that "no showing has been made of legal overvotes uncounted"). 
Second, the Florida Supreme Court faced the challenge of getting county election officials to act. It was easy to anticipate that these officials might be reluctant to engage in the hand counting of ballots. As the Washington Post summarized one election official's attitude, "Hand counting implied something was wrong with the system, which, in turn, implied that something was wrong with the system supervisor." 131 In fact, up to eighteen of the sixty-seven Florida counties did not even carry out a machine recount on November 8 , as was required by state law in such a close election. ${ }^{132}$ These counties either simply reviewed their initial results or conducted spot tests with vote counting machines to confirm their proper functioning. ${ }^{133}$ Rather than asking potentially reluctant counties to do too much, the Florida court tried to set a modest goal. It ordered the county canvassing boards to examine the approximately 60,000 undervotes for false negatives, which were the ballots where a machine failed to register a voter's intent. ${ }^{134}$ As we have seen, this limited order at least somewhat disadvantaged voters in optical (precinct) counties.

The Florida majority believed that the election system's purpose was to ascertain the intent of the voter, and that the judiciary was required to oversee the examination of the undervotes as part of reaching this goal. The majority justices saw their court and the rest of the state judiciary playing a significant role within the election system. The Gore opinion traced this role back to the legislature, which allowed unsuccessful candidates the right first to protest election results before county canvassing boards and then to contest results in court. ${ }^{135}$ With this statutory structure in mind, the majority concluded, "We can only do the best we can to carry out our sworn responsibilities to the justice system and its role in this process." 136

In contrast, the Florida dissenters viewed the election as a process run by the legislative branch and the state's election officials. In this interpretation of the election code, the legislature had assigned the county canvassing boards alone "the authority to ascertain the intent

131 Wash. Post Report, supra note 21, at 125.

132 See Fla. Stat. ch. 102.141(4) (1993). This provision is not, however, a model of legislative clarity. Regarding the failure of all counties to do a machine recount, see Phil Long \& Dan de Vise, Not All Areas Obeyed Order to Do Recount, Miami Herald, Dec. 15, 2000, at 1A; John Mintz \& Peter Slevin, Human Factor Was at Core of Vote Fiasco, Wash. Post, June 1, 2001, at A1.

133 Long \& de Vise, supra note 132, at $1 \mathrm{~A}$.

134 See Gore, 772 So. 2d at 1262.

135 Id. at 1252 . The court particularly noted that, at the contest stage of proceedings, "[r]elief that may be granted is varied and can be extensive." Id.

136 Id. at 1261 n.21. 
of the voter."137 Absent "substantial noncompliance with election laws," the judiciary did not have a role in the election system. ${ }^{138}$ As a result, the dissent argued, Florida's election officials deserved deference in their implementation of election law and in their running of elections. For the judiciary to force further recounting would involve the court in matters where it did not belong and might even force the system into chaos. ${ }^{139}$

Under the circumstances of the election, which included a demonstrated reluctance of county canvassing boards to examine the remaining ballots, the Florida Gore court's order-while limited-was a valid, even heroic, attempt to carry out reform one step at a time. It sought to force adjustment in one election-system component: that which had led to the creation of undervotes. This court refused to let humans shirk their obligations of electoral fairness by hiding behind technology. The combination of technological subsidiarity and technological fallibility demanded judicial intervention.

In a footnote, the court sternly admonished the dissenters. According to the majority justices, the dissenters

would have us throw up our hands and say that because of looming deadlines and practical difficulties we should give up any attempt to have the election of the presidential electors rest upon the vote of Florida citizens as mandated by the Legislature. While we agree that practical difficulties may well end up controlling the outcome of the election we vigorously disagree that we should therefore abandon our responsibility to resolve this election dispute under the rule of law. ${ }^{140}$

The system had failed, and the Gore court wanted to put pressure back on it.

\section{B. The U.S. Supreme Court Bush Dissenters}

Justices John Paul Stevens, David Souter, Ruth Bader Ginsburg, and Stephen Breyer dissented from the U.S. Supreme Court's Bush v. Gore ${ }^{141}$ decision. Although the dissenting Justices emphasized somewhat different points in their opinions, they shared common themes regarding technology. The Bush dissenters generally demonstrated an understanding of the underlying Florida voting technology superior to

137 Id. at 1268 (Wells, C.J., dissenting).

138 Id. at 1264. Chief Justice Wells cogently expressed this view: "Elections involve the other branches of government." Id.

139 Id. This perspective fails to grasp the ability of entrenched interests to use voting technology as a means of retaining power. See infra Part IV.A.2 (discussing political lockup).

140 Gore, 772 So. $2 \mathrm{~d}$ at 1261 n.21.

141531 U.S. 98 (2000) (per curiam). 
that of the Justices in the majority. To be sure, like the Florida Gore court, none of the dissenters in Bush discussed the full measure of the technology used in the Florida election system. Nevertheless, in contrast to the Bush per curiam opinion, which was concerned only with punch-card technology, the dissenters were aware of the presence of other voting technology in Florida. Thus, Souter referred to "the several types of ballots" used in the Florida election and discussed the implication of such diversity for the need, if any, for uniform standards in the manual counting of ballots. ${ }^{142}$

Beyond their glimpse of technological diversity, the Bush dissenters also wrestled with the legal implications of the use of different technologies for voting in Florida. The dissenters shared the epistemology of technology of the Florida Supreme Court's Gore opinion. Regarding the idea of technological subsidiarity, Stevens was the dissenting Justice who most clearly articulated this theme. ${ }^{143} \mathrm{He}$ suffused election machinery with a sense of the organic. For his central metaphor, Stevens cited Justice Oliver Wendell Holmes: “We must remember that the machinery of government would not work if it were not allowed a little play in its joints." 144 For Stevens, the Florida election system was like a machine, but one that required human operators to engage in general tinkering and adjustments as it operated.

An important corollary of Stevens' belief in technological subsidiarity is that he was comfortable with the use of standards rather than rules for the counting of undervotes. As an initial working definition, we can consider a standard to be an open-ended decisionmaking yardstick and a rule, its counterpart, to be a harder-edged decisionmaking tool. ${ }^{145}$ To illustrate, consider the possibilities under the rule-standard dichotomy for regulating the behavior of an automobile driver at a train crossing: (1) stop, look, and listen (the rule), or (2) proceed with reasonable caution (the standard). ${ }^{146}$ Or, to re-

142 Id. at 134-35 (Souter, J., dissenting).

143 Id. at 124-29 (Stevens, J., dissenting).

144 Id. at 126 (citing Bain Peanut Co. of Tex. v. Pinson, 282 U.S. 499, 501 (1931)).

145 For a sampling of the extensive legal literature concerning the rule-standard dichotomy, see, e.g., Louis Kaplow, Rules Versus Standards: An Economic Analysis, 42 Duke L.J. 557 (1992); Duncan Kennedy, Form and Substance in Private Law Adjudication, 89 Harv. L. Rev. 1685 (1976); Carol M. Rose, Crystals and Mud in Property Law, 40 Stan. L. Rev. 577 (1988); Schlag, supra note 9; Kathleen M. Sullivan, The Justices of Rules and Standards, 106 Harv. L. Rev. 22 (1992); Cass R. Sunstein, The Problems with Rules, 83 Cal. L. Rev. 953 (1995).

146 The examples are suggested by two Supreme Court decisions famous in the scholarship about the rule-standard dichotomy: Balt. \& Ohio R.R. v. Goodman, 275 U.S. 66 (1927) and Pokora v. Wabash Ry., 292 U.S. 98 (1934). Schlag starts his classic analysis of the dichotomy with these two cases. Schlag, supra note 9, at 379. 
turn to an issue closer at hand, a rule for counting undervotes would spell out for each technology the permutations of dimples, hanging chads, crosses, marks, and other signs that counted as a legal vote. As we will see in Part III, the Bush majority's per curium opinion viewed human scrutiny of undervotes as presenting dangerous temptations for partiality and demanded the machine-like precision of hard-edged rules to limit discretion. ${ }^{147}$ Instead of a rule, however, the Florida Supreme Court relied on a standard for counting undervotes. It used the standard expressed in the election code by the Florida Legislature: the clear intent of the voter. ${ }^{148}$

For Stevens, the election system in Florida functioned through a series of discretionary choices made by humans who were generally constrained not by rules (as required by the Bush per curiam majority), but by standards. On this issue, Stevens had a valid point-many, although not all, electoral decisions were made in Florida through the use of standards. ${ }^{149}$ Stevens also found that the use of standards would be sufficient for the task of counting undervotes. The key factor was that "a single impartial magistrate" had been given authority to "adjudicate all objections arising from the recount process." 150

As for technological fallibility, Stevens and Breyer both discussed the comparative error rates associated with punch-card and optical scanning systems. Stevens identified the "enormous differences in accuracy" that followed from "Florida's decision to leave to each county the determination of what balloting system to employ."151 Breyer completed this train of thought; he argued that "in a system that allows counties to use different types of voting systems, voters already arrive at the polls with an unequal chance that their votes will be counted."152 It was the Florida Supreme Court's order to have the undervotes counted that "helps to redress this inequity." 153

In addition, Breyer specifically pointed to a newspaper report concerning how "variations in the undervote rate" were "pro-

147 See infra Part III.A.1.

148 Gore v. Harris, 772 So. 2d 1243, 1262 (Fla. 2000) (citing Fla. Stat. ch. 101.5614(5) (Supp. 1994)).

149 Indeed, sometimes rules in the election code contained a standard as well. Thus, the detailed rules for ballot design for voting machines contained a standard-like exception: "The order in which a voting machine ballot is arranged shall as nearly as practicable conform to the requirements of the form of the paper ballot for that election." Fla. Stat. ch. 101.27(3)(1993) (emphasis added).

150 Bush v. Gore, 531 U.S. 98, 126 (2000) (Stevens, J., dissenting).

151 Id.

152 Id. at 147 (Breyer, J., dissenting).

153 Id. 
nounced."154 Breyer clearly expressed his belief in technological subsidiarity and technological fallibility by quoting a Connecticut state court holding: "Whatever the process used to vote and count votes, differences in technology should not furnish a basis for disregarding the bedrock principle that the purpose of the voting process is to ascertain the intent of the voters." 155

As a concluding matter, we should remind ourselves that less than two days passed between the oral argument and publication of the different Bush opinions. ${ }^{156}$ Some people do better than others under tight deadlines, however, and the dissenting justices in Bush, like the Florida Gore majority, grasped the essence of the technological disparities in Florida. The dissenters did not articulate any sweeping equal protection interest in equal access to technology. ${ }^{157}$ But as Justice Ginsburg noted regarding the more limited remedy ordered by the Florida Supreme Court, states are permitted to reform "one step at a time" because "we live in an imperfect world, one in which thousands of votes have not been counted."158 Counting the undervotes would have brought Florida one step closer to equal access to voting. The Supreme Court's Bush majority stopped this step from being taken, and it is the per curiam opinion and Rehnquist concurrence to which we now turn.

\section{III.}

Of Technological Reification and Human Fallibility: The U.S. Supreme Court's Bush Decision

We begin with a puzzle. The per curiam order is unsigned. ${ }^{159} \mathrm{Be}-$ cause all other opinions in Bush v. Gore list the Justices who wrote or joined in them, it is possible to determine that Justices Kennedy and O'Connor provided the two key votes behind the per curiam order. Were it not for their refusal to sign the concurrence by Chief Justice

154 Id. (citing Ford Fessenden, No-Vote Rates Higher in Punch-Card Count, N.Y. Times, Dec. 1, 2000, at A29). In fact, the statistics in this early report underestimated the full measure of the voting-technology divide because they lumped together all optical-scanning systems, whether or not they used central tabulation. Better data, which became available only later, showed that the disparity was even worse than Breyer could have known at that time. See supra Part I.A.

155 In re Election of U.S. Representative for Second Cong. Dist., 653 A.2d 79, 91 (Conn. 1994) (cited in Bush, 531 U.S. at 152 (Breyer, J., dissenting)).

156 As Bruce Ackerman observed, "The Court typically labours for many months before handing down a significant judgment: Bush $v$. Gore was issued 34 hours after the oral argument." Ackerman, supra note 6, at 5.

157 For more discussion of this interest, see generally infra Part IV.A.

158 Bush, 531 U.S. at 143 (Ginsburg, J., dissenting) (citing McDonald v. Bd. of Election Comm'rs of Chi., 394 U.S. 802, 809 (1969)).

159 See id. at 100 (per curiam). 
Rehnquist, which Justices Scalia and Thomas joined, the Chief Justice would likely have written a majority opinion for the Court instead.160

Thus, the puzzle concerns the basis for this split within the bare five-justice majority in Bush. The failure by Justices Kennedy and O'Connor to join the Rehnquist concurrence suggests that we would be wise to search for distinctive arguments in the per curiam order, or perhaps some perceived flaw in the Rehnquist concurrence. Such scrutiny would not be in vain.

The Rehnquist concurrence views Florida election technology as having performed as intended and assigns full responsibility for any uncounted ballots to the would-be voter. In place of technological subsidiarity, Rehnquist embraces technological reification. Technology is no longer an abstraction, or even a means to an end, but is identical with the system's goal. Rehnquist's logic transforms wouldbe voters who do not measure up to the demands of technology into nonvoters. In contrast, the Invisible Justice who wrote the per curiam order acknowledges, if gingerly, the possibilities of flaws in Florida's technology of voting.

For the Invisible Justice, however, any awareness of technological fallibility was trumped by a belief in human fallibility, a belief which is also found in the opinion of the Florida Gore dissenters. The per curiam opinion thus objects to the Florida Supreme Court's order to count all undervotes. Indeed, the per curiam constitutionalizes a requirement that a statewide recount be carried out only with hardedged rules that would cabin the kind of human discretion permitted by more open-ended standards.

\section{A. The Per Curiam Order and Human Fallibility: Rules, Not Standards, or Else}

This Article has argued that the Florida Gore court's adoption of a standard for the counting of undervotes dovetailed with its view of technology. It perceived technology as merely subsidiary to human decisionmaking, and prone to failure at that. Use of a standard would allow a human decisionmaker discretion to respond to different conditions. As we have also seen, although the Florida Gore court and the Bush dissenters alike missed the full range of voting technologies used in the Florida election, they grasped the unequal access to voting caused by the differences among these technologies.

160 For a contention that the Rehnquist concurrence was originally intended to be the majority opinion, see David G. Savage \& Henry Weinstein, 'Right to Vote' Led Justices to 5-4 Ruling, L.A. Times, Dec. 14, 2000, at A1; see also Klarman, supra note 6, at 1733 (finding contention plausible). 
In contrast, the U.S. Supreme Court per curiam opinion ignored the critical issue regarding differences in accuracy among disparate election technologies. Its tunnel vision had an unfortunate consequence: The Invisible Justice behind the per curiam opinion, interested only in how counting punch cards might lead to unfairness, failed to perceive the voting-technology divide in Florida.

\section{Rules and Equal Protection}

The sole focus of the per curiam opinion is the punch-card ballots and a belief that the "clear intent of the voter" standard would lead to unequal treatment of punch-card ballots. The opinion states:

Much of the controversy seems to revolve around ballot cards designed to be perforated by a stylus but which, either through error or deliberate omission, have not been perforated with sufficient precision for a machine to register the perforations. In some cases a piece of the card-a chad-is hanging, say, by two corners. In other cases there is not separation at all, just an indentation. ${ }^{161}$

According to this view, when county canvassing boards and the judges who supervise their work were left to divine the clear intent of the voter from these pieces of punched paper, a fatal constitutional shortcoming arose.

We come now to the heart of the per curiam opinion, which constitutionalizes a "rules" requirement for statewide recounts. The Invisible Justice explains:

[T] he question is not whether to believe a witness but how to interpret the marks or holes or scratches on an inanimate object, a piece of cardboard or paper which, it is said, might not have registered as a vote during the machine count. The factfinder confronts a thing, not a person. ${ }^{162}$

At this moment, the per curiam opinion has reaches a possible dead end: As Stevens observes in his Bush dissent, it is in fact commonplace for the law to use a general standard in many instances in which intent must be assessed. ${ }^{163}$ Stevens referrs to perhaps the best known yardstick of all American law, the "beyond a reasonable doubt" standard:

[T] here is no reason to think that the guidance provided to the factfinders, specifically the various canvassing boards, by the 'intent of the voter' standard is any less sufficient-or will lead to results any less uniform-than, for example, the "beyond a reasonable

161 Bush, 531 U.S. at 105 (per curiam).

162 Id. at 106.

163 Id. at 125-26 (Stevens, J., dissenting). 
doubt' standard employed everyday by ordinary citizens in courtrooms across this country. ${ }^{164}$

As Stevens also pointed out, it is not only that the law in general makes frequent use of standards, but that election law does. Indeed, election law makes frequent use of the precise standard proposed by the Florida Supreme Court-the "intent of the voter." In a footnote that occupies almost a full page of the U.S. Reports, Stevens cites the many election statutes in different states that rely on an "intent of the voter" standard. ${ }^{165}$ Moreover, standards are frequently used to judge intent based on a paper document. Ronald Dworkin suggests the classic example of a contested last will and testament; the deceased testator is no more present than the anonymous Florida voter who left behind a punch card, optical scanner ballot, or paper ballot. ${ }^{166}$ One might also add that the Florida election system, for better or worse, was standard-driven in other areas as well. 167

Faced with the ubiquity of that which she or he would reject, the author of the per curiam opinion decided to brazen it out. First, the Invisible Justice admitted that the law searches for intent "in a multitude of circumstances; and in some cases the general command to ascertain intent is not susceptible to much further refinement."168 But we are then told that those cases are different; we must do more in Bush. We must go beyond "the general command to ascertain intent" because the Constitution requires more. Under this reading of the Equal Protection Clause, these scratched, indented, and punched pieces of paper may be examined only with "specific rules" in place "to ensure uniform treatment."169 No rules, no recount.

The per curiam opinion rests on an epistemology of technology in which machines are generally exacting, and humans-even judgesare prone to prejudice and error. Humans had shifted their standards for the recount from county to county or even "within a single county

164 Id. at 125.

165 Id. at 124 n.2.

166 Dworkin, Response to Fried, supra note 6, at 10. Paper-based evidence is all that is available to a legal factfinder determining "the intention of a deceased testator in writing the will he did." Id. Dworkin chooses this unremarkable example to demonstrate that "the law often instructs judges and juries to determine a person's intention with no more precise directions" than "clear intention." Id. Dworkin adds, "[I]t might well be harder to set out in advance sensible criteria for interpreting the visual clues on a "punched piece of paper' than for interpreting the words of a will ...." Id.

167 For example, counties did not know of the criteria that the state or ChoicePoint Data used in conducting its purge of the voting rolls and, at best, turned to broad standards in deciding how to implement the data lists they received from the state. See Getter, supra note 98, at A1; see generally supra notes 93-101 and accompanying text.

168 Bush, 531 U.S. at 106 (per curiam).

169 Id. 
from one recount team to another."170 And the lack of experience of the judges who would be involved in the recount also bothered the Supreme Court: "The county canvassing boards were forced to pull together ad hoc teams of judges from various Circuits who had no previous training in handling and interpreting ballots." 171 If technology left unexamined ballots, the gray zone in which the ballots existed had to be navigated with rules lest the recount go astray.

As a final element in its logic, the per curiam's insistence on rules rather than standards was grounded on a novel "vote dilution" theory. Without rules in place, certain voters would suffer "arbitrary and disparate treatment."172 At stake, the opinion states, was the Court's "one person, one vote jurisprudence."173 But whose vote would be diluted? The opinion identified two classes of voter victims: those whose ballots were excluded from the Florida Supreme Court's ordered recount (voters who cast overvotes), and those whose votes had already been tallied before the recount. ${ }^{174}$ Without rules in place, says the per curiam, these individuals would be harmed by the recount. It concludes, "The contest provision, as it was mandated by the State Supreme Court, is not well calculated to sustain the confidence that all citizens must have in the outcome of elections." 175

\section{Rules and the Voting-Technology Divide}

Much appears wrong with the per curiam opinion, whether one considers its immediate impact or future consequences. As for the immediate impact, the Supreme Court shut down any further examination of votes in Florida. This result followed the Court's judgment that inadequate time was available to devise the firm rules it deemed necessary-a conclusion based on a dubious reading of the federal safe harbor statute. ${ }^{176}$

A broader, immediate consequence of the decision stems from the Court's decision to protect certain voters from "arbitrary and disparate treatment" by refusing to count their ballots. The Bush Court declared: "Having once granted the right to vote on equal terms, the State may not, by later arbitrary and disparate treatment, value one

170 Id.

171 Id. at 109.

172 Id. at 107.

173 Id.

174 Id. at 107-08.

175 Id. at 109.

176 Id. at 110-11 (interpreting 3 U.S.C. $\$ 5(2000)$ ). Even Charles Fried, in his defense of the Bush decision, admitted that the deadline analysis "was the least convincing portion of the Court's opinion." Fried, supra note 6, at 8. Less charitably, Michael Klarman declared, "The Court manufactured this deadline out of thin air." Klarman, supra note 6, at 1732. 
person's vote over that of another."177 But the State of Florida had not granted the right to vote on equal terms. The voting-technology divide in Florida created "political apartheid" through unequal distribution of technology. ${ }^{178}$ The Supreme Court's vision of equal protection assisted those who voted with better technology and those who had already survived the technology obstacle course.

The proof of this argument is that the Bush decision did nothing to close the voting-technology divide in Florida or elsewhere in the nation. ${ }^{179}$ To satisfy the Bush Court, a state need only have detailed rules that define a "legal vote" for all voting technologies. Note, however, that the Bush Court did not alter the conditions for individual voters who voted with bad technology, such as those in majority-black Gadsden County. ${ }^{180}$ As long as rules are in place for deciding the nature of a "legal vote" in an optical (precinct) county and an optical (central) county, the voters in Gadsden County can still use bad technology and those in Leon County, across the Ochlockonee River, can still use good technology. ${ }^{181}$

So, while the Florida Supreme Court's order to count only undervotes represented an incomplete remedy for voters in Gadsden County, the U.S. Supreme Court offered no remedy at all. The demand for rules for a recount prevented assistance to any voters and failed to close the voting-technology divide in Florida.

The dissenters in Bush spotted this flaw in the per curiam opinion. Concerning the disparate treatment of voters, Breyer noted in dissent that the remedy of counting undervotes itself responded to the unfairness built into the Florida election system. He stated, "By halting the manual recount, and thus ensuring that the uncounted legal

177 Bush, 531 U.S. at 104-05 (per curiam).

178 Shaw v. Reno, 509 U.S. 630, 647 (1993) (describing redistricting technique as "political apartheid"); see infra Part IV.A.3 (comparing Voting Rights Act cases such as Shaw to potential voting-technology divide cases).

179 To the extent that the per curiam opinion mentions technological failure, it does so only grudgingly. As the opinion observs, "[P]unchcard balloting machines can produce an unfortunate number of ballots which are not punched in a clean, complete way by the voter." Bush, 531 U.S. at 104 (per curiam). With an attempt at Solomonic wisdom, the author of this sentence has neatly divided responsibility between: (1) the punch-card machine that produced the "unfortunate number of ballots," and (2) the voter who failed to punch "in a clean, complete way."

180 See supra Part I.B.1 and Table C (analyzing voting-technology divide with reference to Gadsden County).

181 Pam Karlan has tied the Bush Court's logic to other Supreme Court cases that used the Equal Protection Clause to restrict rather than expand rights. Pamela S. Karlan, The Newest Equal Protection: Regressive Doctrine on a Changeable Court, in The Vote, supra note 6 , at 77,89 . According to Karlan, since the Court essentially excluded a previously included group-voters with yet-uncounted votes-its decision did not actually further the interest of any "identifiable individual voter." Id. 
votes will not be counted under any standard, this Court crafts a remedy out of proportion to the asserted harm. And that remedy harms the very fairness interests the Court is attempting to protect."182 As for the notion that counting undervotes harms voters who had cast overvotes, Justice Ginsburg argued in dissent that courts usually permit states to carry out reform one step at a time. ${ }^{183}$

The per curiam opinion was worried about the factfinder's confrontation with "a thing, not a person"184 and sought to protect the thing - a ballot-from unequal treatment by preventing its examination. Jeffrey Rosen's summary regarding this aspect of the Bush opinion is apt: "At least the ballots can sleep peacefully."185

\section{Rules and the Next Technological Failure}

But what of the future impact of this decision? Here, the trend among some scholars is to view the U.S. Supreme Court's opinion as unlikely to leave any legacy. In a highly negative analysis of Bush that characterizes it as a product of a "conservative majority's partisan political preferences," 186 Michael Klarman nevertheless predicts that the decision in this case concerns a constitutional issue that "will rapidly become obsolete."187 Stephen Holmes sees the case as nearly one of a kind and characterizes those who continue to debate it as "law school generals who cannot stop fighting the last war."18s There are grounds to be less sanguine than Klarman and Holmes on this score, however, because of the Court's enshrinement of rules.

Rules for statewide recounts permit election officials to respond to technological shortcomings in close elections only if technology fails in exactly the same way as anticipated. If, as is more likely, different and unanticipated events occur, there normally would be recourse to more general standards. Yet after the Bush decision, no remedy is possible under such circumstances because a recount without rules is constitutionally impermissible. ${ }^{189}$

182 Bush, 531 U.S. at 147 (Breyer, J., dissenting).

183 Id. at 143 (Ginsburg, J., dissenting) (citing McDonald v. Bd. of Election Comm'rs., 394 U.S. 802, 809 (1969); Williamson v. Lee Optical of Okla., Inc., 348 U.S. 483, 489 (1955)).

184 Bush, 531 U.S. at 106 (per curiam).

185 Jeffrey Rosen, Disgrace, New Republic, Dec. 25, 2000, at 18, 20.

186 Klarman, supra note 6 , at 1724.

187 Id. at 1721.

188 Stephen Holmes, Can a Coin-Toss Election Trigger a Constitutional Earthquake?, in The Unfinished Election of 2000, at 235, 250 (Jack N. Rakove ed., 2001).

189 Bush, 531 U.S. at 106 (per curiam). 
Understanding this point requires that we return to the rule-standard dichotomy. ${ }^{190}$ Consider again the possibilities for the behavior of the automobile driver at a railroad crossing: (1) stop, look, and listen (the rule) or (2) proceed with reasonable caution (the standard). In Dean Kathleen Sullivan's account, the choice between a rule or a standard is important not for its impact on the automobile driver, but for the different degrees of constraint that each one imposes on the legal decisionmaker after an event takes place. ${ }^{191}$ If an accident at a railroad crossing is governed by the rule, the legal decisionmaker must inquire whether an automobile driver stopped, looked, and listened. ${ }^{192}$ Equipped with a standard, however, the judge has more freedom to decide which factors to take into account. A standard sends the decisionmaker back to the original policy, such as a requirement of due care in operating an automobile. ${ }^{193}$

The Bush Court articulated a constitutional requirement of hardedged rules that required decisionmakers on the county canvassing boards in Florida-and all future recounters in elections for federal office-to respond in a determinate way to particular facts. ${ }^{194}$ The gray zone in which recounts occur had to be navigated with rules because humans, even judges, are prone to error and unlikely to improve on decisionmaking by machines. This constitutionalized requirement allows a response - a recount - only when a particular error has been anticipated and appropriate rules are already in place.

While hindsight is $20 / 20$, election technology design is not; the next technological failure is likely to occur in a different part of the election system. This prediction can be illustrated by lessons from the world of engineering. In a series of pioneering case studies of engineering failure, Henry Petroski examined a world in which bridges and walkways collapse, semisubmersible oil rigs topple into the ocean, and Grumman buses prove unable to handle the potholes of New York City. ${ }^{195}$ In Petroski's judgment, "[v]irtually all design is conducted in a state of relative ignorance of the full behavior of the system being designed."196 Thus, he suggested, "each new building or

190 See supra notes $143-45$ and accompanying text.

191 Sullivan, supra note 145, at 57-59.

192 See id. at 58 ("A legal directive is 'rule'-like when it binds a decisionmaker to respond in a determinate way to the presence of delimited triggering facts.").

193 See id. at 58-59 ("Standards allow the decisionmaker to take into account all relevant factors or the totality of the circumstances.").

194 See Bush, 531 U.S. at 110 (per curiam).

195 Henry Petroski, Design Paradigms: Case Histories of Error and Judgment in Engineering (1994) [hereinafter Petroski, Design Paradigms]; Henry Petroski, To Engineer is Human (1982) [hereinafter Petroski, To Engineer].

196 Petroski, Design Paradigms, supra note 195, at 93. 
bridge may be considered to be a hypothesis in its own right."197 The hypothesis is that "such and such an arrangement of parts will perform a desired function without fail."198

In a similar manner, each election system is a kind of untested structure or hypothesis. The next time catastrophe strikes Florida's election system, technology likely will fail in a different fashion than it did in 2000. State officials now know, for example, that they must clearly define the parameters used to assess a legal vote in a punchcard ballot. Yet new ambiguities will occur and new challenges will arise in future elections.

For instance, ambiguities might creep in with the introduction of new computerized voting machines similar to ATMs, known as Direct Recording Electronic (DRE) machines. ${ }^{199}$ Like other computers, DRE machines consist of both software and hardware components. ${ }^{200}$ And in DRE machines as in other computers, either or both of these two components is capable of partial malfunction or even complete breakdown.

As an example of hardware failure, consider Intel's Pentium II microchip for personal computers. After its introduction in 1994, accompanied by much fanfare, the Pentium II was found to make a calculating error. ${ }^{201}$ The Pentium II was redesigned and, after some public pressure, Intel agreed to replace all previously distributed Pentium II chips free of charge. ${ }^{202}$

Another example demonstrates a combined failure of hardware and software: In the fall of 2001, 2000 of Citibank's ATMs crashed. Although official spokespersons at Citibank would not comment, the Wall Street Journal reported that the malfunction occurred when Ci-

197 Petroski, To Engineer, supra note 195, at 43.

198 Id. at 44.

199 For my warnings about use of these devices, see Paul M. Schwartz, Bye to Chads; Hello to What?, Nat'1 L.J., June 11, 2001, at A24; see also Caltech/MIT, Residual Votes, supra note 4, at 2; see also infra notes 360-72 and accompanying text (discussing inherent problems with Direct Recording Electronic (DRE) technology).

200 See Gen. Accounting Office, No. GAO-02-3, Elections: Perspectives on Activities and Challenges Across the Nation 44-47 (2001) [hereinafter GAO Report] (describing DRE technology).

201 Intel downplayed the error at first and stated that most users would never see the bug, but other reports spoke of the chip possibly affecting routine calculations. See Laurie Flynn, Some Companies Report Pentium Problem, N.Y. Times, Dec. 19, 1994, at D1 (reporting on widespread complaints from Pentium II users and tests by IBM showing error could occur "as often as once every 24 days for the average user"); Jim Seymour, Intel Should Face Mistake So It Can Face Customers, PC Week, Dec. 5, 1994, at 46 (calling Intel's claims about insignificance of error "nonsense").

202 Lawrence M. Fisher, Intel Earnings Decline 37\% on Charge for Pentium Flaw, N.Y. Times, Jan. 18, 1995, at D4 (reporting that Intel took pretax charge to pay for replacement of flawed chips). 
tibank tried to integrate the data systems of a recently acquired bank with its own computer systems, which then "buckled under the sudden surge in activity." 203 The Citibank example is particularly notable not only because DRE technology is so often compared to an ATM, but also in light of the suggestion that DRE machines "can be configured to electronically transmit the vote totals from the polling place to a central tally location."204 This is just the kind of communication that appears to have triggered the Citibank crash. ${ }^{205}$

If software or hardware flaws occur in DRE machines, the Florida Secretary of State's proposed rules for carrying out recounts and judging voter intent leave much unspecified. The new provisions stipulate that, in the event of a recount involving DRE machines: "A manual recount shall be conducted by printing out or exporting the ballot image files and counting these files manually."206 But otherwise, the proposal is incomplete and ignores the questions that are most likely to arise should DRE machines malfunction.

If election officials suspect either software or hardware failure, should they examine and perhaps repair the machines before "printing out or exporting the ballot image files" or not? If so, who shall carry out any alterations to either software or hardware? Should these alterations be limited in scope? More specifically, can new lines of software be supplied if the old software has developed a bug?207 If a chip in a machine has failed, can a new one be installed? Finally, one also can imagine that lost votes might be recovered from a balky machine by examining its hard drive for stored ballot information, much as one searches a personal computer's hard drive to recover drafts of memos or e-mails after a system crash. When will a DRE machine's hard drive contain sufficient data to constitute a valid "ballot image file"? How much of an image is required to constitute proof of voter intent?

The Florida Secretary of State's new regulations fail to address any of these issues because they are, in fact, more like standards than

203 Jathon Sapsford \& Paul Beckett, Crash Dodging: Financial Firms Work to Rewire Old Technology, Wall St. J., Sept. 7, 2001, at C1.

204 See GAO Report, supra note 200, at 47.

205 See Sapsford \& Beckett, supra note 203 (noting that ATM crash was caused partly by Citibank's efforts to install new software linking its ATM control system to regional ATM networks in other states).

206 Proposed Rule 1S-2.031, 28 Fla. Admin. Weekly $301 \S 2.031$ (2)(j) (Fla. Dep't of State Jan. 25, 2002), LEXSEE 28 FAW 301.

207 After Citibank's ATM failure, there was a "scramble among the nation's biggest financial houses" to upgrade computer networks-in part by using "fix-it software" and more customized rewriting of programming instructions. Sapsford \& Beckett, supra note 203. Would election officials be allowed to react similarly? 
rules. Where questions like those posed above are unanswered, we presumably are left to plug gaps with the overarching standard in Florida's new election law, which calls for counting a vote "if there is a clear indication on the ballot that the voter has made a definite choice."208 This outcome beautifully illustrates Duncan Kennedy's point that an apparent rule may really be "a covert standard." 209 We can only hope that a future Florida election using DRE machines does not prove another point of Kennedy's: These masquerading rules may create "a dynamic instability as pernicious as that of standards." 210

Of course, flaws in DRE machines are just one type of unanticipated problem that could arise within an election system; other technologies, election ecologies, and legal ambiguities can also raise unexpected problems and cause difficulties with inflexible rules. ${ }^{211}$ Another place where ambiguities may arise is when rules in the election code are broken. Ballot designs for the November 2000 election in several counties, including the butterfly ballot in Palm Beach County, violated Florida's detailed rules for design of ballots.212 When rules elsewhere in the election system are not followed, rules for a recount may fail to provide adequate benchmarks. In addition, absentee ballots, whose use is expanding in Florida and elsewhere in the nation, raise other challenges for rules, because solitary voters complete them without receiving the kind of feedback and general assistance that are available to reduce error when one votes in person.

These illustrations suggest just a few ways in which election systems might fail in their task of ascertaining the voters' will. Future failures could just as easily come from completely unexpected directions-underscoring the danger of approaching them, as the Bush per curiam demands, with hard-edged rules alone.

\footnotetext{
208 Fla. Stat. Ann. \$ 102.166 (West Supp. 2002).

209 Kennedy, supra note 145, at 1701.

210 Id.
}

211 See Dworkin, Badly Flawed, supra note 6, at 55 ("[I]nevitable uncertainties and ambiguities in election law will have to be faced anew in each close election, because even if Florida's law is clarified now, the next set of contests will arise in an entirely different state with an entirely different structure of law and ambiguity."); see also Kennedy, supra note 145, at 1697-1701 (making similar and more general point about movement from rules to standards); Rose, supra note 145, at 578-80 (arguing that natural movement of law is from standards to rules and then back to standards as rules become uncertain in light of changing circumstances and their own inevitable incompleteness); Sunstein, supra note 145, at 993-94 (noting tendency of rules to be outrun by changing circumstances).

212 See supra notes 88-91 and accompanying text; see also supra note 48 (describing failure of election workers to remedy problems that caused faulty test ballots before polls opened). 


\section{B. The Rehnquist Three and Technological Reification: Follow the Instructions, or Else}

While the per curiam addressed its concern about human fallibility with an insistence on hard-edged rules, the Rehnquist concurrence simply denied that technological failure took place in the Florida election at all. Rehnquist's argument is summed up in his declaration that "Florida statutory law cannot reasonably be thought to require the counting of improperly marked ballots." 213 Rather, the Chief Justice believed that any failure was that of voters who neglected to follow instructions. The resulting ballots represented nonvotes, and thus were not legal under Florida law. Rehnquist rests his argument on an exaltation of technology.

Rehnquist centers his concurrence on the judgment that the Florida Supreme Court's interpretation of the Florida election code was erroneous-indeed, even "absurd."214 In Rehnquist's view, the Florida Supreme Court rewrote the election code in the guise of interpreting it. First, Rehnquist objected to the Florida Supreme Court's interpretation of statutory language concerning deadlines, the certification of voters, and the level of discretion to be granted decisions of the Florida Secretary of State. ${ }^{215}$ The Chief Justice then turned to the critical final act of alleged judicial revision by the Florida Supreme Court, which concerned its interpretation of a "legal vote." 216 In disagreeing with this reading of the election code, Rehnquist's concurrence confronted voting technology.

In this part of the concurrence, Rehnquist engaged in a kind of systems analysis. This discussion is highly compressed, at times even cryptic, and therefore requires especially careful examination. Rehnquist argued that the Florida election code perceived voting as taking place through a double bargain that imposed duties both on the governmental officials who ran the election and on voters. ${ }^{217} \mathrm{He}$ concluded that: (1) Florida officials carried out their required tasks, and (2) those voters who created undervotes had not. Rehnquist's approach has numerous flaws, however, and they concern both sides of the double bargain.

213 Bush v. Gore, 531 U.S. 98, 118-19 (2000) (Rehnquist, C.J., concurring).

214 Id. at 119.

215 Id. at $117-20$.

216 Id. at 118.

217 Id. at 119. 


\section{Florida's Obligations}

The Chief Justice first explained Florida's part of the bargain. Rehnquist led with his conclusion, which I have already quoted: "Florida statutory law cannot reasonably be thought to require the counting of improperly marked ballots." $218 \mathrm{He}$ then listed three elements of the state's election code: "Each Florida precinct before election day provides instructions on how properly to cast a vote, each polling place on election day contains a working model of the voting machine it uses, and each voting booth contains a sample ballot."219 The rhetorical tactic here is subtle, but it fails to mask three problematic aspects of this list of state-side duties.

First, the Chief Justice did not discuss whether each Florida precinct actually fulfilled the requirements placed on it. Rather, by citing the legislative code in the present tense, he sought to convey the impression that the Florida election system in fact performed as legally required: The precinct "provides instructions"; the polling place "contains a working model"; and the "voting booth contains a sample ballot." Without addressing the issue directly, Rehnquist deftly created the impression that Florida had carried out these three commandments. In fact, as this Article has demonstrated, the Florida election system did not perform well. Consider initially Rehnquist's statement about sample ballots. There may or may not have been accurate sample ballots in all of the voting booths in each of Florida's 5885 precincts, but the law also requires publication of sample ballots in newspapers, and we do know that in Duval County, at least, the sample ballot published in newspapers had incorrect voting instructions. ${ }^{220}$ As for the precincts' obligation to provide instructions, the Los Angeles Times found, "Nearly every county was swamped by complaints of inexperienced poll workers who couldn't answer questions, didn't know the law and unfairly turned away registered voters." 221

Second, Rehnquist did not explore the extent to which the three requirements he cited are the exclusive ones. Consistent with his elliptic approach, Rehnquist never stated that these three obligations are the only ones, or the only relevant ones, placed on election officials. He simply presents them as if they were. Here, too, he manages

218 Id. at 118-19. This sentence introduces the theme of nonvotes, which Rehnquist calls "improperly marked ballots."

219 Id. at 119 (citations omitted).

220 Miami Herald Report, supra note 21, at 115-16. For the statutory requirement that sample ballots be published in a newspaper, see Fla. Stat. Ann. § 101.20(2) (West Supp. 1982). Sample ballots are to be "in the form of the official ballot as it will appear ... on election day." $\$ 101.20(1)$.

221 Drogin, supra note 64 , at A1. 
to appear to answer a question without having raised it. Yet, as this Article has shown, election officials had other obligations, and in many circumstances these were not met. Some of these shortcomings violated the Florida election code or federal election law, such as failing to provide adequate language assistance, 222 removing eligible voters from the voting rolls, ${ }^{223}$ and allowing the use of equipment after preelection tests uncovered problems with it. ${ }^{224}$

Finally, Rehnquist did not discuss the extent to which his list of state-side obligations points to any larger statutory aim. At a minimum, these requirements indicate a legislative intention that precincts familiarize voters with voting technology. More broadly, they provide evidence that the Florida legislature wanted to protect fairness in voting. However, a court seeking to identify and evaluate these statutory goals would be obliged to look at other elements of the Florida electoral code, relevant legislative history, and existing Florida case law on the subject.225 Instead, Rehnquist's interpretative jurisprudence picks and chooses among pieces of statutory language-despite his willingness to discern evidence of such larger statutory purposes in other parts of his Bush concurrence. 226 This narrowly focused micro-tour of

222 Compare Civil Rights Comm'n, supra note 22, at 81-83 (finding "large numbers" of voters needing language assistance were denied it) with 42 U.S.C. \$ 1973aa-1a(c) (1994) (requiring states to provide single-language minority groups with voting assistance and materials in appropriate language).

223 See supra notes 93-101 and accompanying text (discussing problems with Florida's purge of voter rolls).

224 Compare supra notes 48-49 and accompanying text (describing malfunctions and test ballots) Fla. Stat. Ann. $\S 101.35$ (West Supp. 2002) (describing preelection tests of voting machines to make sure they are fully functional).

225 The Florida Supreme Court's opinion, in contrast to the Rehnquist concurrence, carefully engaged in these interpretive tasks. See Gore v. Harris, 772 So. $2 d 1243,1248-54$ (Fla. 2000) (per curiam).

226 I refer to the Article II theory at the heart of Rehnquist's concurrence, which depends on demanding deference to the purposes seen in a broad statutory scheme. Because of my focus on the different approaches to technology revealed by the different opinions in this case, I have not yet mentioned this argument. The Chief Justice maintained that Article II of the U.S. Constitution empowered the state legislatures and thus required courts to defer to legislatures and "those bodies expressly empowered by the legislature to carry out its constitutional mandate." Bush v. Gore, 531 U.S. 98, 114 (2000) (Rehnquist, C.J., concurring). He found that the Florida Supreme Court "significantly departed from the statutory framework in place on November 7" and therefore violated Article II. Id. at 122.

Fried and Posner alike consider this Article II argument superior to the per curiam's equal protection argument, see Fried, supra note 6, at 8; Posner, Deadlock, supra note 6, at 152-57, although Posner admits, "There is undoubted irony in interpreting the [U.S.] Constitution broadly to force state courts to interpret their election laws narrowly." Posner, Deadlock, supra note 6 , at 157 .

Larry Kramer, however, is withering in his criticism of the Rehnquist concurrence for constitutionalizing this question of statutory interpretation. He first faults the opinion for its utter failure to inquire into the original intent of the Founders in drafting Article II. Kramer, supra note 6, at 123-25. ("The real problem with the Article II argument is simply 
Florida's election code managed, despite a bare minimum of actual contact with Florida law, to create an incorrect impression that the state had kept its part of the statutory bargain with voters.

\section{The Voters' Obligations}

What, then, is required of voters? Here too, the Chief Justice's presentation and analysis are cryptic. The linchpin of his argument, as we shall see, is that Florida election law did not intend undervotes to be counted. Rehnquist begins, however, with a quotation from the actual voting instructions:

In precincts using punchcard ballots, voters are instructed to punch out the ballot cleanly: 'AFTER VOTING, CHECK YOUR BALLOT CARD TO BE SURE YOUR VOTING SELECTIONS ARE CLEARLY AND CLEANLY PUNCHED AND THERE ARE NO CHIPS LEFT HANGING ON THE BACK OF THE CARD.'227

In black and white, there it is: no chips (or, in the now famous terminology, chads) allowed.

Not only were these instructions clear, according to the Chief Justice, but, equally important, the voting machines were designed specifically to read only cleanly punched holes. ${ }^{228} \mathrm{He}$ therefore considered it impossible for a "reasonable person" to find a recount justifiedunder the standards he cited-in circumstances "when electronic or electromechanical equipment performs precisely in the manner designed, and fails to count those ballots that are not marked in the manner that these voting instructions explicitly and prominently specify."229

that it makes no sense. It works only if one reads the words of the Constitution completely out of context and pretends that they were meant to do something they were not, and for no good reason."). Later, Kramer sums up his critique of the statutory interpretation issue:

Where a statute is ambiguous, interpretation is unavoidable, and someone's choice among the plausible alternatives must prevail. But Article II cannot possibly be read to say that this someone should be the U.S. Supreme Court, certainly not unless the state court ignored clear and unambiguous statutory language, which simply was not the case here.

Id. at 145; cf. Richard H. Pildes, Judging "New Law" in Election Disputes, 29 Fla. St. U. L. Rev. 691, 726-29 (2001) (criticizing Rehnquist concurrence's finding of "new law" in Florida Supreme Court ruling as inconsistent with other federal interpretations of "new law" in election context).

227 Bush, 531 U.S. at 119 (Rehnquist, C.J., concurring) (citations omitted). For a photograph of similar voting instructions placed in the voting booths of Miami-Dade County, see Miami Herald Report, supra note 21, at photo page after 154.

228 Bush, 531 U.S. at 119 (Rehnquist, C.J., concurring).

229 Id. (citing standards concerning tabulation error from Fla. Stat. Ann. $§ 102.166(15)$ (Supp. 2000) and concerning rejection of "legal votes" from $\$ 102.168(3)(c)$ ). 
If a properly functioning machine did not read a ballot after an individual failed to punch a hole properly, Rehnquist concluded, then that ballot cannot be a vote. Technology did not fail; the voter did. The consequence of this shortcoming under Florida law is the creation of a nonvote. Rehnquist sums up his systems analysis in this fashion:

The scheme that the Florida Supreme Court's opinion attributes to the legislature is one in which machines are required to be "capable of correctly counting votes," but which nonetheless regularly produces elections in which legal votes are predictably not tabulated, so that in close elections manual recounts are regularly required. This is of course absurd. ${ }^{230}$

In other words, the Florida election system was designed to leave such ballots uncounted.

Where the Invisible Justice felt that voting technology might have played some role in the creation of incorrectly punched ballots, the Chief Justice perceived only failure on the part of the voter. Where the Invisible Justice wished to control discretion in any recount through hard-edged rules, Rehnquist saw manual examination of the undervotes as an "absurd" result that violated the plain meaning of Florida law. Rehnquist views Florida as having lived up to its part of the electoral bargain, its technology as having functioned as intended, and people whose ballots were not counted by vote-counting machinery as nonvoters who failed to meet their obligations. ${ }^{231}$ Or, as one Florida election official explained to a reporter some months after the Bush decision, "People should know how to vote."232

\section{Rehnquist's Technology Obstacle Course}

As a systems analyst, Rehnquist came up woefully short. By centering his analysis around an exalted view of technology, he misread the Florida election system. Had only two more Justices joined his opinion, Rehnquist would have created a precedent with devastating consequences for future elections.

We can best understand Rehnquist's reification of technology and misreading of Florida law if we return to his explanation of Florida's “double bargain." In LoPucki's view, a systems analyst "attempts to

230 Id. (citing Fla. Stat. Ann. \$ 101.5606(4) (West Supp. 2002). As Charles Fried approvingly restated this conclusion, the Florida court had turned Florida law "completely on its head." Fried, supra note 6 , at 8.

231 The Miami Herald Report summed matters up differently: "Crowds and confusion. Bad ballot design and defective equipment. It was a recipe for a flawed election, and a bad election is what Florida got." Miami Herald Report, supra note 21, at 75.

232 Drogin, supra note 64, at A1 (quoting Gadsden County election official Denny Hutchinson). For further examples of election supervisors (and the Florida Secretary of State) blaming voters, see Miami Herald Report, supra note 21, at 66-67. 
accommodate as much complexity as possible. A comprehensive description of the system's functioning is a precondition to the analysis."233 Instead, Rehnquist began with a dubious intimation that Florida had lived up to its part of the bargain. Rehnquist put election technology on a pedestal; he found it absurd to think that a state might purchase machines that could not read imperfect ballots and require these ballots to be examined manually in close elections.

If this Article has shown one thing thus far, it is that technology does not belong on a pedestal. Rehnquist engaged in myth-making regarding Florida's choice of punch-card technology. He also conveniently ignored the other voting technologies in use in the state. The Florida election system evolved over time and incorporated different election technologies, including devices other than punch-card machines, with inevitable shortcomings and contradictions in the selection process.

Furthermore, the Chief Justice overlooked the strong influence of financial constraints on each county's choice regarding which voting technologies to acquire. ${ }^{234}$ In fact, Florida's system imperative, which was having elections that reflected the will of the people, was accompanied by a strong secondary goal of running elections at the lowest possible financial cost. ${ }^{235}$

Meeting this secondary system goal of cheap elections was particularly difficult because of the growth of Florida's population. Spending on the election system remained a low priority even as the number of registered voters in Florida nearly tripled between 1970 and 2000.236 In the four years from 1996 to 2000 alone, 700,000 people were added to Florida's voting rolls. ${ }^{237}$ Florida did not decertify less accurate voting machines, but permitted counties to save money by

233 LoPucki, Systems Approach, supra note 13, at 481.

234 See generally Civil Rights Comm'n, supra note 22, at 45-55.

235 In its low spending on elections, Florida followed a national trend. So little is spent on voting equipment and election supplies in the United States that "the residential lawnmower industry [is] more than ten times the size of the entire election industry." Caltech/ MIT, What Could Be, supra note 74, at 53. As a national commission headed by former Presidents Gerald Ford and Jimmy Carter noted, when county and city governments are forced to balance competing needs, "the election infrastructure of democracy loses." Nat. Comm'n on Fed. Election Reform, To Assure Pride and Confidence in the Electoral Process 68 (Aug. 2001) [hereinafter Carter-Ford Comm'n] ("It is commonplace to find local budgets that spend ten times more on parks and recreation, or on solid waste, than on running elections."), available at http://www.reformelections.org/data/reports/ 99_full_report.pdf.

236 Florida Task Force, supra note 3, at 16 (discussing explosion in growth of number of registered voters in Florida).

237 Id. at $16 \&$ chart 2. 
continuing to use them-with the result that counties had widely varying levels of voting accuracy.

Given these technological shortcomings, the law required humans to count ballots when elections were close as a safety valve. In fact, human checking of ballots was and is an established Florida tradition, which the 2001 Florida election reform law reaffirmed.238 From his incorrect starting point that the entire election system was built around the creaky punch-card counting machines, Rehnquist mistakenly deduced that Florida law intended any ballots not read by these devices to be illegal ones.

Not only was Rehnquist wrong about the punch-card counting machines in the Florida election system, his concurrence would establish a toxic precedent for future elections. The Rehnquist concurrence provides no disincentive for incompetence in ballot design and selection of technology. Should a state bungle its use of election technology, it will be the voter who suffers the harm of having cast an "illegal" vote.

Moreover, Rehnquist's epistemology of technology creates an incentive for states to select and utilize election technology that rewards voters based on their ability to navigate a technology obstacle course. As long as the state expresses a requirement somewhere in the voting instructions that was not met by some voters, the resulting votes can be deemed "illegal" and left uncounted. The concurrence thus allows the politically powerful to engage in gamesmanship when managing an election system. As the next Part demonstrates, such gamesmanship is a sad historical reality that lives on today due to political lockup. ${ }^{239}$ These problems demand a view of technology more flexible and purposive than the Bush majority embraces.

IV.

\section{Election Technology, Equal Access, and Reform}

The Florida election system was not created in a single moment, but developed over time. It was shaped by legislation, decentralized choices at the county and precinct level, and judicial decisions. Not surprisingly, the election system that resulted from these many influences at different times had inconsistencies and weak points. As LoPucki generally states, "[T]here is no expectation that the system's operation will ever be completely consistent with the system's goals.

238 See Fla. Stat. Ann. $\S 102.166$ (West Supp. 2002) (requiring manual recounts in close elections); Proposed Rule 1S-2.031, 28 Fla. Admin. Weekly 301 (Fla. Dep't of State Jan. 25, 2002), LEXSEE $28 \mathrm{FAW} 301$. (proposing recount procedures).

239 See infra Part IV.A.2. 
The analyst almost inevitably discovers some malfunction in the system and can suggest some possibilities for improving it."240

Thus, a critic of election-system design is unlikely to face difficulties in spotting errors. Indeed, a number of reports issued in the year after the 2000 election sounded the alarm about a wide range of systemic problems nationwide. ${ }^{241}$ Rather, the challenging task will be designing an election system capable of coordinating activities in a fashion that permits its functioning to improve over time. A normative model of election-system design must be concerned with institutional structure, decisionmaking power, and how different subparts of affected bureaucracies share knowledge. Many elements of this task of model-building are likely to be state specific.

This Article has demonstrated that an election system structure can result in unequal access to the electoral process. As in Florida, this inequality can take place through a voting-technology divide. In this final Part, I turn to the efforts to reform the design of elections systems using litigation and legislation.

The first question is a normative one: What aspects of a representative democracy are harmed by this inequality? After describing the interests at stake, I consider how political lockup can influence technology and election-system design to limit equal access to voting. I suggest that such inequality in deployment of election technology violates both the Equal Protection Clause and section 2 of the Voting Rights Act and necessitates judicial intervention.

Then, in Part IV.B, I turn to legislative and administrative efforts at both the federal and state levels to reform the unfair deployment of voting technology and other flawed aspects of election ecologies. These proposals are stalled in most jurisdictions and suffer from shortcomings where they have been enacted.

\section{A. Participation and Voice, Political Lockup, and a Judicial Response}

\section{The Interest in Equal Access}

Election systems have a singular place in a democracy, and their use of technology raises the momentous issue of equal access to the

240 LoPucki, Systems Approach, supra note 13, at 502.

241 See, e.g., Caltech/MIT, What Could Be, supra note 74, at 3 (calling for "significant investment by the federal government in research and development of voting equipment technologies"); Democratic Investigative Staff, House Comm. on the Judiciary, How to Make Over One Million Votes Disappear 17 (Aug. 20, 2001) [hereinafter House Judiciary Democratic Staff Report] (identifying "serious deficiencies . . . in the conduct of elections in virtually every state"), available at http://www/house.gov/judiciary_democrats/electionreport.pdf; GAO Report, supra note 200, at 24 (documenting "major challenges involving the people, processes, and technology involved at each stage of the election process"). 
electoral process. Any inequality in the deployment of these systems should be viewed as harming the interests of the people in both: (1) participation in government and (2) having their voice heard through voting.

In Reynolds $v$. Sims, the U.S. Supreme Court clearly identified the first interest, the link between voting and participation in government. 242 In this important 1964 opinion, Chief Justice Earl Warren discussed a contested election to a state legislature:

Legislators represent people, not trees or acres. Legislators are elected by voters, not farms or cities or economic interests. As long as ours is a representative form of government, and our legislatures are those instruments of government elected directly by and directly representative of the people, the right to elect legislators in a free and unimpaired fashion is a bedrock of our political system. ${ }^{243}$

Representative government is self-government through the medium of the people's chosen representatives. From this perspective, equal access to voting matters because it allows citizens to participate in government. ${ }^{244}$ As the Florida election demonstrates, however, equal access to the vote cannot take place when there is a voting-technology divide.

Beyond participation, voting also is tied to an interest in having the people's voice heard in political life. The Florida Supreme Court's Gore opinion expressed this idea in terms of the obligation under Florida law that elections express "the will of the voters." 245 It also quoted an earlier Florida Supreme Court opinion on this point: "The right to vote is the right to participate; it is also the right to speak, but more importantly the right to be heard." "246 The cited case was from 1975, but the Florida Supreme Court could have relied on almost a century of legal precedent in that state concerning the need for out-

242377 U.S. 533, 555 (1964) ("The right to vote freely for the candidate of one's choice is of the essence of a democratic society, and any restrictions on that right strike at the heart of representative government.").

243 Id. at 562.

244 On the idea of voting as participation, Ellen Katz reminds us that during much of the nineteenth century, "voter turnout was high and elections were events of considerable pageantry." Ellen D. Katz, Race and the Right to Vote After Rice v. Cayetano, 99 Mich. L. Rev. 491, 528 (2000). Katz argues that the right to vote produces two benefits: "the constitutive benefit an individual derives from political engagement with others and the expressive benefit derived from full membership in the political community." Id. at 495. Both of these benefits sound in the participatory interest identified here. For a further discussion of the participatory interest, see generally Pamela S. Karlan, The Rights to Vote: Some Pessimism About Formalism, 71 Tex. L. Rev. 1705, 1708 (1993) (developing idea of voting as participation, defined as "the formal ability of individuals to enter into the electoral process by casting a ballot").

245 Gore v. Harris, 772 So. 2d 1243, 1254 (Fla. 2000) (per curiam).

246 Id. (quoting Boardman v. Esteva, 323 So. 2d 259, 263 (Fla. 1975)). 
comes that reflect the will of the voter. ${ }^{247}$ For the court, this principle and the litigation before it involved "the essence of the structure of our democratic society." 248

To permit the voice of the people to be heard, an election system must devote considerable resources toward the task of obtaining an accurate final result. This does not entail a search for the kind of precision that in our world is often impossible, or for a kind of truth that is perhaps unknowable. It does mean, however, that an election outcome cannot be said to be just when there is unequal access to the franchise. Given the disparities discussed in Part I, access to the vote now must be extended to an interest in equal access to election technology. Without such a guarantee, the people's voice cannot be said to be heard.

To the extent that some scholars consider voting rights as including a group-based aspect, this dimension of voice also involves an interest in equal access to voting. As Samuel Issacharoff has explained, "To be effective, a voter's ballot must stand a meaningful chance of effective aggregation with those of like-minded voters to claim a just share of electoral results." 249 Without equal access to voting, this chance of effective aggregation with like-minded voters will not exist.

Election systems play a central role in the United States; the interests they protect are at the core of our democratic order. Yet election systems frequently have weaknesses and shortcomings. Even more troubling, these systems often do not correct themselves. Flaws in the design of systems and the use of technology persist over years and even decades. As one technology expert reported recently to Computer Professionals for Social Responsibility, "Elections experts have been writing since the [19]70s on the inadequacy of U.S. election systems. Unfortunately, systems that were inadequate in 1970 are still

247 The line of relevant cases begins with Darby v. State ex rel. McCollough, 75 So. 411, 412 (Fla. 1917) (per curiam). For other Florida case law on the importance of "the will of the people" being reflected in final election outcomes, see Boardman, 323 So. $2 \mathrm{~d}$ at 267; State ex rel. Carpenter v. Barber, 198 So. 49, 50-51 (Fla. 1940); Wiggins v. State ex rel. Drane, 144 So. 62,63 (Fla. 1932).

248 Gore, 772 So. $2 \mathrm{~d}$ at 1253.

249 Samuel Issacharoff, Groups and the Right to Vote, 44 Emory L.J. 869, 883 (1995). To be sure, the idea of a group right to vote is controversial. For example, Issacharoff raises the objection that it can lead to a racial and ethnic spoils system that will be destructive to the integrative ideal of the civil rights movement. Id. at 900-908. For other perspectives, see Heather K. Gerken, Understanding the Right to an Undiluted Vote, 114 Harv. L. Rev. 1663, 1681-91 (2001) (discussing concept of "aggregate rights" for vote dilution claims); Spencer Overton, A Place at the Table: Bush v. Gore Through the Lens of Race, 29 Fla. St. U. L. Rev. 469, 490 (2001) ("Many Americans of various backgrounds . . use voting as a means to maintain communities of identity and to exert collective self-determination in shaping their world through the political process."). 
in use today, and are still inadequate."250 Or as USA Today summed up the matter in a headline: "Rampant Flaws Leave Citizens Without Voice in Democracy: Thousands Are Denied Vote, and Problems Are Not New."251

To err is human, but some mistakes matter more than others. The disastrous shortcomings in election technology and election-system design are those that lead people to be frozen out of the electoral process. An unacceptable system flaw is one which blocks an election system from carrying out its two functions: allowing people to participate in government and permitting the voice of the people to be heard.

\section{The Problem of Political Lockup}

The longtime persistence of these problems in the election system can be attributed in large part to the problem of political lockup, a term which refers to the distortion and manipulation of political processes by in-groups in order to maintain their power. ${ }^{252}$ John Hart Ely famously identified the problem of elected representatives and governmental officials "clogging the channels of change" and "acting as accessories to majority tyranny." 253 A leading election law casebook opens by warning in similar terms that "those who control existing arrangements have the capacity to shape, manipulate, and distort democratic processes."254 The deployment of election technology provides a technique for establishing and maintaining political lockup.

Not only does lockup insulate the currently powerful "ins" from accountability, but it also entrenches other inequalities in society. For example, we have seen how the unequal distribution of voting technology in Florida correlated with disparities of race and wealth. ${ }^{255}$ This distortion may be explained, at least in part, by political lockup. Because blacks are among the groups most likely to vote for candi-

250 Erik Nilsson, Getting the Chad Out: Elections, Technology, and Reform, CPSR Newsletter, Winter 2001, at 1 (noting that complaints about punch-card machines date to 1970s), available at http://www.cpsr.org/publications/newsletters/issues/2001/Winter; see also Miami Herald Report, supra note 23, at 60. A 1988 report for the National Bureau of Standards argued for the elimination of "pre-scored punch ballots," which over a decade later were still in use in Florida. See Saltman, supra note 40, at 5.

251 Peter Eisler \& Laura Parker, Rampant Flaws Leave Citizens Without Voice in Democracy, USA Today, Apr. 6, 2001, at 3A.

252 See Issacharoff, Karlan \& Pildes, supra note 87, at 2.

253 John Hart Ely, Democracy and Distrust: A Theory of Judicial Review 103 (1980).

254 Issacharoff, Karlan \& Pildes, supra note 87, at 2.

255 See supra Part I.B.1. 
dates of one party (Democratic), 256 the other party (Republican) has a particularly strong incentive to permit racial disparities in the distribution of voting technology. The resulting denial of black participation and voice maintains the tarnished record in the United States of violations of the voting rights of blacks. ${ }^{257}$

There has in fact been a long tradition in the United States of designing election systems to block access to the franchise by racial minorities and the poor. As an example of gamesmanship through election systems, consider the history in the United States of the government-distributed secret ballot, also known as the "Australian ballot."258 In the late nineteenth century, before the introduction of the Australian ballot, voters utilized preprinted ballots that political parties distributed before the election. In a leading account of the right to vote in the United States, Alexander Keyssar summarizes voting behavior in this period: "All that a man had to do was drop a ballot in a box." 259 The disadvantage of this approach was a lack of secrecy: "Since ballots tended to be of different sizes, shapes, and colors, a man's vote was hardly a secret-to election officials, party bosses, employers, or anyone else watching the polls." 260

In contrast to these nonsecret ballots, the Australian ballot, usually printed by the government, lists all the candidates in standardized form and is used by all voters. ${ }^{261}$ Although this added secrecy to the voting process, some states intentionally designed complicated ballots to confuse illiterate or less educated voters. ${ }^{262}$ These excerpts from the 1892 campaign song of the Arkansas Democratic Party regarding the ballot used in that year's election prove the point:

And when a [N]egro gets a ballot

He has certainly met his match. . .

They go into the booth alone

Their ticket to prepare

And as soon as five minutes are out

256 In Florida, Gore was the choice of nine out of ten black voters. Wash. Post Report, supra note 21 , at 76 .

257 Much of the history of the franchise in the United States has, of course, concerned black disenfranchisement and the political and legal struggle to end it. See generally Issacharoff, Karlan \& Pildes, supra note 87, at 90-129; Alexander Keyssar, The Right to Vote: The Contested History of Democracy in the United States 111-16, 256-66 (2000).

258 Keyssar, supra note 257, at 142.

259 Id.

$260 \mathrm{Id}$.

$261 \mathrm{Id}$.

262 Id. at 143 ("The Australian ballot was, however, an obstacle to participation by many illiterate foreign-born voters in the North, as well as uneducated black voters in the South."); John William Graves, Negro Disfranchisement in Arkansas, 26 Ark. Hist. Q. 199, 212-13 (1967) (describing complicated format of typical printed ballot). 
They have got to git from there. ${ }^{263}$

Thus, because of political lockup, a reform targeting one unfairness led to creation of another.

Candidates compete with one another for votes, but voters should not be required to compete with each other at the polling place. Put differently, an election system is undemocratic when it rewards voters based on their ability to navigate a technological obstacle course or to follow instructions. And in Florida in November 2000, as in Arkansas in 1892, the law explicitly forbade a voter from occupying the booth for longer than five minutes. ${ }^{264}$

The great danger of this type of political lockup underscores the need for judicial action to protect voting rights. ${ }^{265}$ In Ely's view, our government can be said to be "malfunctioning" when "the ins are choking off the channels of political change to ensure that they will stay in and the outs will stay out." 266 When such behavior occurs, Ely argues, "the process is undeserving of trust." $267 \mathrm{He}$ calls for judicial action not only to prevent outright "denial of the vote," but also "[o]ther practices that go to the core of the right of the people to choose their representatives." 268

From a systems analyst's perspective, the election system had already been manipulated by the time the first voters appeared in the precincts on the morning of November 7, 2000. Contrary to the U.S. Supreme Court's crabbed view of the proper judicial role in elections $^{269}$ (shared by the dissenters in the Florida court's Gore decision $^{270}$ ), the reality of political lockup and unequal access to voting technology provide ample basis for courts to scrutinize the use of technology to count votes. As the next subsection argues, several existing legal provisions invite this type of involvement in future cases where the questions are presented directly.

263 Graves, supra note 262 , at 212-13.

264 Fla. Stat. Ann. § 101.51(1) (West Supp. 2002).

265 Ely, supra note 253, at 116-25 (arguing for judicial review of voting process based on danger of political lockup).

266 Id. at 103.

267 Id. (emphasis removed). In a useful aside during this broader discussion about the danger of the "outs" being frozen out by the "ins," Ely observes, "A referee analogy is also not far off: the referee is to intervene only when one team is gaining unfair advantage ...." Id.

268 Id. at $117 \& \mathrm{n}$ **.

269 See generally Bush v. Gore, 531 U.S. 98, 104-11 (2000) (per curiam); supra Part III.A.

270 See Gore v. Harris, 772 So. 2d 1243, 1264 (Fla. 2000) (Wells, C.J., dissenting) (warning that elections are "political contests" and that courts need "the self-discipline not to become embroiled in them"); supra notes 135-37 and accompanying text (discussing Florida Supreme Court's Gore dissent). 


\section{Judicial Responses to Voting-Technology Lockup}

The Equal Protection Clause of the Constitution and section 2 of the Voting Rights Act provide a twin legal response to inequalities in election-system design. ${ }^{271}$ To begin with the Equal Protection Clause, the unequal distribution of election technology causes harm to voters that should be seen as violating the Constitution. ${ }^{272}$ First, there are great concrete harms to individuals following from the unequal distribution of voting technology. Assignment of good voting technologies to some voters and bad ones to others wastes more votes in certain counties. To borrow the language of the Supreme Court's racial gerrymandering case law, this creates "vote dilution." 273 In Shaw $v$. Reno, the Supreme Court warned against the state establishing "political apartheid" by employing certain race-based redistricting techniques. ${ }^{274}$ The voting-technology divide in Florida in the November 2000 election created "political apartheid" through an unequal distribution of voting technology. The voters assigned to bad voting machines suffered concrete harms. ${ }^{275}$

Beyond these concrete injuries, Shaw also confronted two "complex and sensitive issues": "the meaning of the constitutional 'right' to vote, and the propriety of race-based state legislation designed to benefit members of historically disadvantaged racial minority groups." 276 The Court found that a reapportionment plan designed to help disadvantaged groups can, under certain circumstances, violate the Equal

271 See U.S. Const. amend. XIV, $\$ 1$ (prohibiting states from denying to any person "the equal protection of the laws"); 42 U.S.C. $\$ 1973$ (a) (1994) (prohibiting state from imposing or applying any "voting qualification or prerequisite to voting or standard, practice or procedure" that "results in a denial or abridgement of the right of any citizen of the United States to vote on account of race or color" or contravenes statute's protection for members of specified language minorities).

272 For a view regarding the Equal Protection Clause similar to my own, see Karlan, supra note 181, at 77. The Supreme Court, of course, took a different approach in Bush $v$. Gore. See supra Part III.

273 For some major cases from this line, see, e.g., Bush v. Vera, 517 U.S. 952 (1996); Johnson v. DeGrandy, 512 U.S. 997 (1994); Holder v. Hall, 512 U.S. 874 (1994); Shaw v. Reno, 509 U.S. 630 (1993); Growe v. Emison, 507 U.S. 25 (1993); Thornburg v. Gingles, 478 U.S. 30,47 (1986).

274509 U.S. at $647-48$.

275 Richard Briffault has made a similar argument: "Equal protection ought to apply to the nitty-gritty of local election practices because those practices can have the effect of disenfranchising voters and discriminating among identifiable groups of voters." Richard Briffault, Bush v. Gore as an Equal Protection Case, 29 Fla. St. U. L. Rev. 325, 326 (2001). His summary of U.S. Supreme Court case law in this area magnifies the point: "Once a state or locality provides that an election is used to fill a public office or to answer a governmental question, then all adult citizens who are residents of the jurisdiction are presumptively entitled to vote in that election, and all voters must have equally weighted votes." Id. at 347 (emphasis added).

276509 U.S. at 633 . 
Protection Clause.277 According to a persuasive interpretation of Shaw by Richard Pildes and Richard Niemi, the Court was worried not only about concrete harms violative of the Equal Protection Clause, but also about "expressive harms," that is, the state's creation of appearances that express "a value structure that offends constitutional principles." 278

The opinion for the Court in Shaw was written by Justice O'Connor, who seven years later provided a decisive vote for the Bush Court. In Shaw, O'Connor stated, "We believe that reapportionment is one area in which appearances do matter."279 In her view, the state action of lumping voters together only because of their skin color sends a pernicious message to voters and their elected representatives. 280 The creation and maintenance of a voting-technology divide for voters, however, sends an equally pernicious message. When the state assigns poor voting technology to certain voters, it expresses a view that their votes count less-as they will, in fact, have less chance of being counted. This appearance creates an "expressive harm."281

As for section 2 of the Voting Rights Act, it prohibits voting practices and procedures that result in a denial of equal electoral opportunity. ${ }^{282}$ The essence of a claim under section 2, the Supreme Court has declared, "is that a certain electoral law, practice, or structure interacts with social and historical conditions to cause an inequality in the opportunities enjoyed by black and white voters to elect their preferred representatives."283 In Florida and other states with similar electoral schemes in 2000 , the practice of technological inequality denied minority voters an equal opportunity to elect candidates of their choice.

Beyond this initial requirement in section 2 cases, Supreme Court precedent also demands that a court be able to find a benchmark for comparisons. This requirement calls for the trial court to identify the contours of an acceptable system for minority voters. ${ }^{284}$ In racial redistricting cases, these kinds of geographic benchmarks can be diffi-

277 Id. at 649.

278 Richard H. Pildes \& Richard G. Niemi, Expressive Harms, 'Bizarre Districts,' and Voting Rights: Evaluating Election-District Appearances After Shaw v. Reno, 92 Mich. L. Rev. 483, 508-09 (1993).

279509 U.S. at 647.

280 Id. at $647-48$.

281 Pildes \& Niemi, supra note 278, at 506-09.

282 Voting Rights Act, 42 U.S.C. § 1973 (1994).

283 Thornburg v. Gingles, 478 U.S. 30, 47 (1986). For an overview of section 2, see

Daniel Hays Lowenstein \& Richard L. Hasen, Election Law 228-81 (2d ed. 2001).

284 Holder v. Hall, 512 U.S. 874, 880 (1994). 
cult to identify. ${ }^{285}$ In contrast, in the context of the voting-technology divide, courts easily will be able to find "a reasonable alternative practice as a benchmark against which to measure the existing voting practice."286 The alternative practices are those on the better side of the voting-technology divide: the good voting technology that is made available to some voters, but not all. ${ }^{287}$

Voting-rights litigation pursuing these theories is now underway in a handful of states. Cases have been filed in Florida, California, and Illinois. 288 Plaintiffs in California secured an early victory when a federal district judge ordered California to eliminate punch-card machines by March 2004. ${ }^{289}$ It remains to be seen whether such positive judicial intervention to counteract political lockup and close the voting-technology divide will continue in future cases.

\section{B. Stalled Election Reform}

I conclude by reviewing the status of statutory election reform since the Supreme Court's Bush decision. The main developments have been continued debate at the federal level and enactment of reform laws in three states (Maryland, Georgia, and Florida). An analysis of these efforts reveals mixed results at best.

\section{Federal Reform Attempts}

Initially, attempts at federal election reform were stalled-indeed, we had here a vivid demonstration of political lockup. ${ }^{290}$ Two

285 See Gingles, 478 U.S. at 58 (concluding that "there is no simple doctrinal test for the existence of legally significant racial bloc voting"); see also Holder, 512 U.S. at 881 ("[T]he search for a benchmark is quite problematic when a $\$ 2$ dilution challenge is brought to the size of a government body.").

286 Holder, 512 U.S. at 880.

287 See supra Part I.A; Table A.

288 For an overview of litigation in different states, see Election Reform Info. Project, What's Changed, What Hasn't, and Why: Election Reform Since November 2000, at 12-14 (Oct. 22, 2001), http://www.electionline.org/site/docs/pdf/electionline.report.10.22.2001.pdf; see also B.J. Palermo, Rights Groups Latch onto Bush v. Gore, Nat'l L.J., May 21, 2001, at A1. For descriptions of two such cases filed by the ACLU, see Press Release, ACLU of Illinois, High Number of Voting Irregularities Leads to Federal Lawsuit Challenging Constitutionality of Illinois Election Process (Jan. 11, 2001), http://aclu.org/news/2001/ n011101a.html; Press Release, ACLU of Northern California, ACLU Files Suit Challenging California's Voting System (Apr. 17, 2001), http://www.aclunc.org/pressrel/010417vote.html.

289 Common Cause v. Jones, No, 01-03470 SVW (C.D. Cal. Feb. 19, 2002) (order).

290 In the words of an editorial in the New York Times a few months after the Bush decision, "The issue of election reform has become merely another partisan battleground." Editorial, Election Reform Stalls, N.Y. Times, Apr. 30, 2001, at A18. State officials were similarly resistant to change at first. In his April 2001 testimony before Congress, for example, Ohio Secretary of State J. Kenneth Blackwell characterized the available financial resources for election reform at the state level as "few or nonexistent," and said that any 
bipartisan Senate bills were introduced in the immediate aftermath of the Florida election. ${ }^{291}$ But they received scant attention at first, and Senator John McCain complained about his colleagues' lack of interest in election reform: "It's a classic example of what happens when an issue fades from the headlines. It drops far down on the priority list."292 In the House of Representatives, attempts to establish a select committee on election reform collapsed when Republican leaders refused to allow parity to Democrats on the proposed committee. ${ }^{293}$ As for the executive branch, its first proposed budget, issued just months after the 2000 election, lacked funds not only for states that wish to improve their voting equipment or running of elections, but even for study of the subject. ${ }^{294}$

Part of the problem in Washington is innate skepticism by elected officials about any changes to the methods that allowed each of them to be elected. As Ely observed about reapportionment of voting districts, the incentive of elected officials is to maintain the system, good or bad, "that got and keeps them where they are."295 Moreover, where Democrats have traditionally favored streamlining registration requirements ${ }^{296}$ and are now interested in spending on better voting technology, Republicans are primarily interested in increasing the integrity of voter registration rolls and making it easier for absentees and military personnel overseas to vote. ${ }^{297}$ To the extent that mem-

upgrading of voting systems had to compete with other important areas, including road construction. Katherine Q. Seelye, Little Change Forecast for Election Process, N.Y. Times, Apr. 26, 2001, at A14.

291 McConnell-Torricelli Election Reform Act of 2001, S. 218, 107th Cong. (2001); Schumer-Brownback Voting Study and Improvement Act of 2000, S. 3273, 106th Cong. (2000).

292 Walter Shapiro, Congress Chooses to Forget an Electoral Bad Dream, USA Today, Apr. 27, 2001, at 4A.

293 Juliet Eilperin, House Fails to Create Election Reform Panel, Wash. Post, Mar. 29, 2001, at A16.

294 Shapiro, supra note 292, at $4 \mathrm{~A}$. The first Bush budget also diminished the chances of involvement by the Federal Election Commission in election reform. The administration refused the commission's request for $\$ 5.5$ million over two years for election reform efforts. and instead cut $\$ 1.4$ million from its $\$ 42.8$ million budget request. See Jim Drinkard, White House Rejects Election-Reform Request, USA Today, Mar. 21, 2001, at 11A. A columnist in the Economist strongly criticized this funding priority: "[T]he president's cavalier decision to reject the Federal Election Commission's request for extra money was nothing short of disgraceful." Lexington, Remember Florida, and Weep, Economist, Apr. 28,2001 , at 34 .

295 Ely, supra note 253, at 121.

296 Issacharoff, Karlan \& Pildes, supra note 87, at 136-37 (describing partisan positions on early "motor voter" legislation as based on assumptions that it would benefit Democrats).

297 See generally President George W. Bush, Remarks at Rose Garden Ceremony on National Election Reform Commission Report, July 31, 2001, LEXIS, Federal News Service (outlining President Bush's "four fundamental principles" of election reform, including emphasis on safeguarding military and absentee ballots); Election Reform Info. 
bers of either party believe that changes in any single area might hurt them, lockup is likely for just the reason Ely identified.

By the beginning of 2002, the initial inaction on federal voting reform had abated somewhat. President Bush's second budget proposal included $\$ 400$ million to start a revolving fund that would loan states money to help pay for upgrading voting technology. ${ }^{298}$ Meanwhile, the Senate and House each coalesced behind respective legislative approaches, and some observers felt Congress might be able to end its impasse and enact a bill. ${ }^{299}$ The House passed a bill sponsored by Representative Robert W. Ney. ${ }^{300}$ The Senate passed a bill by Senator Christopher J. Dodd, ${ }^{301}$ which had been amended to reflect the results of bipartisan negotiations. ${ }^{302}$

The two pieces of proposed legislation share some good qualities. Both provide federal funding to replace obsolete voting technology. ${ }^{303}$

Project, supra note 288 at 3-4 (Oct. 22, 2001), http://www.electionline.org/site/docs/pdf/ electionline.report.10.22.2001.pdf (discussing partisan differences); David S. Broder, Electoral Reform, A Hit Last Fall, Goes Amiss, Wash. Post, Apr. 21, 2001, at A1 (reporting on partisan tensions over electoral reform). E.J. Dionne has suggested considering the voting equipment issue separately from more difficult topics, "for example, how to keep voting rolls up to date without unfairly purging legitimate voters from the lists." E.J. Dionne, Jr., Op-ed, Elections on the Level, Wash. Post, July 24, 2001, at A21.

298 David S. Broder, Bush Budget to Back Election Reform, Wash. Post, Jan. 16, 2002, at A8. The idea of a revolving fund came from the commission headed by former Presidents Jimmy Carter and Gerald Ford. See Carter-Ford Comm'n, supra note 235, at 72-73. While better than nothing, the revolving fund concept has problems: Once federal grants dry up, state and local commitment to technology reform is likely to end. A minority of the Carter-Ford commission's membership objected to this approach on these grounds. See infra notes 323-27 and accompanying text (discussing disagreement within Carter-Ford commission).

299 See Dan Carney, Election Reform Looks Like a Shoo-In, Bus. Wk., Jan. 14, 2002, at 43 (observing that election reform issue "seems to have been resurrected by something that happens all too rarely in Washington: a compromise that makes both sides feel they've won"); David E. Rosenbaum, Ending Impasse, Senate Leaders Agree to Overhaul Nation's Voting Systems, N.Y. Times, Dec. 14, 2001, at A33 (predicting that "the agreement announced today makes it likely that legislation to improve voting systems will be enacted next year").

300 Help America Vote Act of 2001, H.R. 3295, 107th Cong. (2001). The House passed the bill by a 362-63 vote on December 12, 2001. Bill Summary and Status Report, http:// thomas.loc.gov (last visited Apr. 23, 2002).

301 The Dodd bill was introduced as the Equal Protection of Voting Rights Act of 2001, S. 565, 107th Cong. (2001). The Senate passed the bill by a 99-1 vote on April 11, 2002. Bill Summary and Status Report, http://thomas.loc.gov (last visited Apr. 23, 2002).

302 The amendment is S. Amend. 2688, 107th Cong. (2001), 147 Cong. Rec. S13764 (daily ed. Dec. 19, 2001). My analysis here concentrates on the amended Dodd Bill, but occasionally points out its differences with the original-and superior-version. For a description of the amended Dodd bill and a prediction of difficult negotiations between the House and Senate, see Dan Seligson, Senate Set to Pass Election Reform Bill: Conference Committee Showdown Looms, Electionline Wkly, Jan. 24, 2002, at http:// www.electionline.org.

303 H.R. $3295 \S 501$ (a)(2); S. Amend. $2688 \S \S 201-210$. 
Both would establish new permanent federal election entities to provide information about election-system performance and to administer voting-system standards. ${ }^{304}$ The two bills also give much-needed attention to assisting voters with disabilities, including those with visual impairment. ${ }^{305}$ Finally, both proposals would permit voters to cast provisional ballots if their eligibility were questioned by election officials on election day. ${ }^{306}$

Unfortunately, these advances are tarnished by the failure of both bills to address two fundamental issues: (1) In both bills, any new federal standards are far from truly mandatory and are difficult to enforce, and (2) even where the bills acknowledge the importance of feedback, they do little to guarantee it. While the amended Dodd bill is somewhat stronger than the Ney bill in both respects, neither one would close the voting-technology divide in the United States if enacted.

The Ney bill expresses a very limited set of "minimum standards" for state election systems. ${ }^{307}$ A state is to self-certify that it meets these standards, with restricted federal enforcement. ${ }^{308}$ Beyond these few requirements, an Election Assistance Commission would set entirely voluntary guidelines-but these would be toothless, as states would remain eligible for federal financial assistance whether or not the standards were met. ${ }^{309}$ As Representative John Conyers, Jr. ob-

304 H.R. 3295 § 212; S. Amend. 2688 § 301.

305 H.R. $3295 \S 502(6)$; S. Amend. $2688 \S 101(\mathrm{a})(3)$. A recent fifty-state survey of election systems determined that "disabled voters faced obstacles to voting in nearly every state." House Judiciary Democratic Staff Report, supra note 241, at 14. The situation may soon start improving, however; the Caltech/MIT Voting Technology Project has found that the voting equipment industry has started to address these accessibility issues. See Caltech/MIT, What Could Be, supra note 74, at 25 .

306 H.R. $3295 \S 502(3)$; S. Amend. 2688 \$ 102(a). The House bill's language includes a loophole that allows states to avoid the use of provisional ballots by claiming to provide "an alternative that achieves the same objective." H.R. 3295 § 502(3). This loophole in the Ney bill was one of the reasons that Representative John Conyers, Jr., the ranking Democrat on the House Judiciary Committee, opposed the legislation. See Press Release, Representative John Conyers, Jr., Conyers Strongly Opposes Ney Bill (Nov. 14, 2001), http:// www.house.gov/conyers (listing Conyers's specific objections to Ney bill).

307 H.R. $3295 \S 502$. These standards represent a bare-bones approach to "best practices." For example, states are to have in place an official statewide voter registration system, provisional voting for every voter who claims to be qualified, uniform standards for defining what counts as a vote, and practical and effective means for voters with physical disabilities to cast a secret ballot. Id.

308 Id. $\S 501$ (establishing self-certification by states); id. $\S 503$ (limiting federal enforcement to situations where state fails to certify, certifications contain falsehoods, or states violate their certifications).

309 Id. $\$ 231$ (c) ("Nothing in this part may be construed to require a State to implement any of the voluntary standards adopted by the Commission with respect to any matter as a condition for receiving an Election Fund payment."). 
jected, "The bill allows states to grade themselves on whether they have met [the standards]. This is like putting the fox in charge of the hen house." 310

The amended Dodd bill sets somewhat more ambitious standards for each voting system used in elections for federal offices. ${ }^{311}$ Unfortunately, just after expressing these supposedly mandatory requirements, the Dodd bill includes this curious language: "Nothing in this section shall require a jurisdiction to change the voting system or systems ... used in an election in order to be in compliance with this Act." 312 This broad language, added to the revised Dodd bill, 313 removes any real federal pressure on states to meet the standards. In addition, the compromise Dodd bill delays all enforcement of the standards until January 2010-a "safe harbor" sheltering states from accountability through another two presidential elections and four congressional elections. ${ }^{314}$

The problem with voluntary standards rather than mandatory ones is the likelihood that local election officials will not step forward to volunteer. A recent study by the General Accounting Office found that election officials reported themselves satisfied with the performance of their voting equipment during the November 2000 election in a striking ninety-six percent of jurisdictions. ${ }^{315}$ This rate is especially surprising because the same study, based on similar self-reporting, found that fifty-seven percent of voting jurisdictions nationwide reported "major problems in conducting the November election." 316 Furthermore, funding incentives are an unstable mechanism for ensuring compliance when congressional attention to election reform may

310 Press Release, Representative John Conyers, Jr., Conyers Says Ney-Hoyer Isn't Half a Loaf (Dec. 5, 2001), http://www.house.gov/conyers.

311 S. Amend. $2688 \$ 101$. Among the positive highlights of these standards is the establishment of a national standard for an acceptable error rate. Id. $\$ 101(a)(5)$ (delegating responsibility to develop acceptable error rates for voting-systems technology to director of Office of Election Administration of Federal Election Commission). Another is a requirement that voting systems be accessible to individuals with disabilities. Id. § 101(a)(3). For example, voting systems would be required to provide nonvisual accessibility for the blind and visually impaired. Id. $\$ 101(a)(3)(A)$. Voting systems are also generally to incorporate "alternative language accessibility" to assist individuals with limited proficiency in the English language. Id. \$101(a)(4)(A). To make recounts possible and allow oversight of system performance, a voting system is to produce "a record with an audit capacity." Id. $\S 101(\mathrm{a})(2)$.

312 Id. § 101(d).

313 Compare id. with S. 565, 107th Cong. (2001).

314 S. Amend. $2688 \S 104(\mathrm{~b})(1)$. The one exception to the safe harbor is the requirement that voting systems be accessible for voters with physical disabilities. Id. $\$ 104(\mathrm{~b})(2)$.

315 See GAO Report, supra note 200, at 254.

316 Id. at 158. 
wane in later annual appropriations processes. ${ }^{317}$ This analysis suggests that such easily satisfied state election officials are unlikely reformers. ${ }^{318}$

As for the importance of feedback, the Ney bill overlooks it entirely. In both its own minimum standards and the guidelines to be developed by the Election Assistance Commission, the legislation focuses only on giving voters an opportunity to correct errors. ${ }^{319}$ Voters should be able not only to correct ballot mistakes, but also to receive system feedback informing them about the possibility of errors in their ballot. The amended Dodd bill at least recognizes the critical role that feedback to voters can provide in protecting equality of the franchise. ${ }^{320}$ But a major compromise here has gutted the strong language of the original legislation. . $^{321}$ As amended, the bill exempts jurisdictions that use a paper-ballot voting system or a punch-card system from the feedback requirement. ${ }^{322}$ All these jurisdictions need to do is establish a voter-education program that "notifies each voter of the effect of casting multiple votes for an office" and, as in the Ney bill, give voters an opportunity to correct ballots before casting them. ${ }^{323}$ As a result, of the three technologies found on the bad side of the voting-technology divide in Florida's 2000 elections, only one-

317 See E. Joshua Rosenkranz, Learning to Count, Am. Prospect, Sept. 10, 2001, at 14 (arguing that posing solution to election flaws as fiscal bargain "is to invite states to drop the standards the moment the federal dollars dry up"); see also infra notes 326-27 and accompanying text (discussing opposition to this approach from minority of Carter-Ford national commission).

318 One is reminded of a quotation about thin-skinned election officials cited earlier: "Hand counting implied something was wrong with the system, which, in turn, implied that something was wrong with the system supervisor." See supra note 131 and accompanying text.

319 The error-correction standards apply only if a jurisdiction switches to an entirely new voting system, in which case it must merely give "voters the opportunity to correct errors before the vote is cast." See H.R. 3295, 107th Cong. $\$ 502(7)$ (2001); see also Conyers, supra note 310 (criticizing this omission from Ney bill).

320 See S. Amend. $2688 \S 101$ (a)(1)(A) (requiring feedback).

321 As introduced, the Dodd bill would have required that a voting system notify voters when they have overvotes or undervotes, as well as permit them to correct their ballots if they did so in error. See S. 565, 107th Cong. $\$ 301(a)(2)$ (2001) (requiring that when voter "selects votes for more than one candidate for a single office," voting system must "notify the voter before the ballot is cast and tabulated of the effect of casting multiple votes for the office" and "provide the voter with the opportunity to correct the ballot before the ballot is cast and tabulated"); id. $\$ 301$ (a)(3) (requiring similar feedback concerning undervotes). These provisions followed a recommendation of a report by the Democratic staff of the House Judiciary Committee commissioned by Representative Conyers, the committee's ranking member. See House Judiciary Democratic Staff Report, supra note 241 , at $118-19$.

322 S. Amend. $2688 \S 101(\mathrm{a})(1)(\mathrm{B})$.

323 Id. 
optical (central) - would be affected by the amended Dodd bill's feedback mandate. ${ }^{324}$

While the weaknesses in these bills resulted in part from the vested interests of elected officials in voting systems, political lockup is not the only cause of disputes about voting reform and the inadequate compromises that may result. Consider the independent $\mathrm{Na-}$ tional Commission on Election Reform, with Presidents Jimmy Carter and Gerald Ford as honorary cochairs, which issued a report with a long list of recommendations for change. ${ }^{325}$

In theory, this privately sponsored entity might have been able to avoid some of the pressures that led to political lockup. Regarding election technology, the report sought a federal role in developing "a comprehensive set of voting-equipment standards for the benefit of state and local election administration." 326 But the commission, like Congress, would leave it largely to state and local election officials to decide how and if they would apply these standards, with federal funds to help them. ${ }^{327}$ A minority statement dissented from this approach, declaring that "certain reforms are fundamental enough to stand on their own as requirements, independent of any federal largesse" and are "too fundamental to be framed as some intergovernmental fiscal deal, bargained out through an appropriations process." 328

The report adopted by the Carter-Ford Commission's majority hardly lived up to its promise as an independent advocate for closing the nation's voting-technology divide. ${ }^{329}$ Since federal reform seems destined to rely on the goodwill of state and local officials, this Section now turns to their efforts to enact election reform.

324 See supra Part I.A; supra Table A.

325 The report called for allowing the use of provisional ballots, providing an opportunity for voters not found on a voter registration list to prove their eligibility, creating statewide databases of eligible voters, permitting citizens with felony convictions to vote once they have served their sentence, and adopting uniform standards for what counts as a vote. See Carter-Ford Comm'n, supra note 235, at 6-14. The organization's home page is located at http://www.reformelections.org (last visited Mar. 12, 2002).

326 Carter-Ford Comm'n, supra note 235, at 9.

327 Id. at 13-14. In addition, the commission's majority only called for an indirect federal grant-matching approach to encourage states to make its proposals into reality. Id. It also left wide discretion to the states to set their own benchmarks for acceptable levels of residual votes, "taking local circumstances into account." Id. The commission's own suggestion was that the benchmark should be set no higher than two percent residual votes, with a goal of "further reductions in succeeding cycles." Id. at 53.

328 Id. at 78 (minority statement of Christopher Edley et al.).

329 Cf. William Raspberry, A Flawed Fix, Wash. Post, Aug. 3, 2001, at A19 ("[I]t was a mouse of a report, calculated to produce consensus but precious little reform."). 


\section{State Reform Attempts}

Since November 2000, only three states have enacted laws comprehensively reforming their election systems. ${ }^{330}$ One of the three, Maryland, already had a good record with running elections: Its number of residual votes for president in the election cycles from 1980 to 2000 declined from $1.14 \%$ all the way to $0.52 \% .331$ Nevertheless, a statewide task force did identify significant variations in the number of residual votes according to voting technology and recommended a shift to a unitary system for the state. ${ }^{332}$ Maryland legislators promptly enacted this suggestion into law, making a good system better. 333

Maryland, however, is unique. The other two states to undertake reform had statewide election systems with serious preexisting flaws. One of the two was Florida. The other was Georgia; like Florida, Georgia used a patchwork of different voting technologies in the November 2000 election. ${ }^{334}$ Georgia actually had a greater percentage of residual votes in the 2000 presidential election than Florida: 3.5\% compared with $2.9 \% .335$ As Georgia Secretary of State Cathy Cox observed, "[I]f the presidential margin had been razor thin in Georgia and if our election systems had undergone the same microscopic scrutiny that Florida endured, we would have fared no better. In many respects, we might have fared even worse." 336

Florida and Georgia enacted election reform laws that are a mixed bag. ${ }^{337}$ The good news begins with the movement away from punch cards. Both legislatures enacted laws that will prevent future use of punch-card voting technologies. ${ }^{338}$ Both statutes also promote

330 Edward Walsh, A Year After Contested Election, Few States Have Made Changes, Wash. Post, Nov. 6, 2001, at A3 (noting that only Florida, Georgia, and Maryland have enacted significant reform legislation).

331 Special Comm. on Voting Systems and Election Procedures in Maryland, Report and Recommendations 104 (Feb. 2001), available at http://www.sos.state.md.us/sos/admin/pdf/ reportall1.pdf.

332 Id. at $7,115$.

333 See H.B. 1457, 2001 Leg., 415 Sess. (Md. 2001).

334 The shortcomings of the Georgia system are set out in a comprehensive official report by Georgia's secretary of state. See Cathy Cox, The 2000 Election: A Wake-Up Call for Reform and Change 6-9 (2001) [hereinafter Georgia Report] (on file with the New York University Law Review), available at http://www.sos.state.ga.us/acrobat/elections/ 2000_election_report.pdf (last visited Mar. 28, 2002).

335 Id. at 3.

336 Carter-Ford Comm'n, supra note 235, at 1.

337 See Florida Election Reform Act of 2001, 2001 Fla. Sess. Law Serv. 2001-40; S. Bill 213, 2001 ALS 3, 338-65 (Ga. 2001).

338 In Florida, the legislature decertified punch-card voting technology. Fla. Stat. Ann. $\S 101.5604$ (West Supp. 2002) (requiring county to use electronic or electromechanical precinct-count tabulation voting system). In Georgia, the legislature has enacted a require- 
greater transparency concerning voting technology. In Florida, public reports on the functioning of voting technology after each election will provide needed transparency concerning the functioning of system components. ${ }^{339}$ Georgia established a pilot project to test electronic voting equipment in selected precincts in municipal elections in 2001.340

The final piece of good news is that Florida will make $\$ 5.9$ million available for both voter education and training of poll workers. ${ }^{341}$ The low, almost nonexistent expenditures on these two areas before the November 2000 election showed mistaken priorities in a democracy. ${ }^{342}$ Yet larger investments in voter education and poll worker training will be required over the long term.

The news regarding voter education and election staff training is more mixed in Georgia than in Florida. The problem of poorly trained election workers is well-documented in Georgia. ${ }^{343}$ The Georgia reform law gives responsibility to the secretary of state for developing and implementing a continuing program for education of voters and election officers. ${ }^{344}$ Unfortunately, the law also appears to pass the costs of this training onto individual counties. ${ }^{345}$ In the November 2000 election, Georgia had approximately 2.6 million participating voters spread over 159 counties; 346 Florida, by comparison, had almost six million participating voters in just 67 counties. ${ }^{347}$ With this large number of Georgia counties, extreme differences will exist in the financial ability of each county to train election officials. It was a mistake for the reform law to base voter education and poll worker training on each county's ability to pay. This part of the law makes it likely that the Georgia election system will have harsher overall voting ecologies in its less affluent counties.

ment of uniform voting technology for the next presidential election, Ga. Code Ann. $\$ 21$ 2-300 (Lexis Supp. 2001), which is likely to result in the adoption of computerized DRE technology. See infra notes 365-66 and accompanying text.

339 Fla. Stat. Ann. § 101.595.

$340 \mathrm{Ga}$. Code Ann. § 21-2-301.

$3412001 \mathrm{Fla}$. Sess. Law Serv. Ch. 2001-40 \$ 74 (C.S.S.B. 1118) (West).

342 For information on Florida's low rate of spending, see U.S. Civil Rights Comm'n, supra note 22 , at $45-55$.

343 Georgia Report, supra note 334, at 12 (finding inadequate "training and indoctrination of election staff" and lack of understanding by poll workers and poll managers "of the election laws and regulations they are responsible for enforcing").

344 Ga. Code Ann. § 21-2-300(d).

345 Id.

346 See Georgia Report, supra note 334, at 6-7.

347 See Florida Task Force, supra note 3, at 31-33. 
The mixed electoral reform news continues with the funding in Florida of a statewide database of eligible voters. ${ }^{348}$ Normally, activity to increase the integrity of the voting process would be a good thing. As this Article has discussed, however, Florida's manipulation of voter registration information before the November 2000 election led to a preelection purge of eligible voters in some counties. ${ }^{349}$ The maintenance of this statewide list raises similar genuine risks. ${ }^{350}$ Due to the previous lack of transparency in this area and official eagerness to throw eligible voters off election rolls in the past, the Justice Department and civil rights organizations should closely monitor how Florida implements its voter registration database. ${ }^{351}$

Unfortunately, two aspects of the statute cause concern. First, Florida has set an impossibly short deadline for election officials to decide whether or not provisional ballots are valid. ${ }^{352}$ Second, under the new Florida election law, provisional ballots are valid only if cast in the precinct to which the voter is assigned. ${ }^{353}$ Provisional ballots cast in the wrong precinct will be rejected entirely, even for national, statewide, or countywide races for which the precinct is irrelevant. ${ }^{354}$ One danger is that harried poll workers simply will hand out provi-

348 Fla. Stat. Ann. $\$ 98.0977$ (West Supp. 2002).

349 See supra notes $93-100$ and accompanying text.

350 See Gregory Palast, The Wrong Way to Fix the Vote, Wash. Post, June 10, 2001, at B1 (stating that single statewide database of voters "creates the potential for new errors on a much greater scale and opens to [sic] the door to political manipulations that are harder to detect than the old ballot-stuffing games, and nearly impossible to prosecute").

351 The dangers of this database might be somewhat ameliorated by a provision of the Florida reform law that permits voters to use provisional ballots when their eligibility is questioned, and places the responsibility on county canvassing boards to verify their eligibility. Fla. Stat. Ann. $\$ \S 97.021(25), 101.048$. The effectiveness of this provisional ballot rule will depend on the details of its organization and use. As noted earlier, the National Commission on Electoral Reform called for the use of provisional ballots, see supra note 325 , as do congressional proposals, see supra note 306 and accompanying text.

352 The law currently gives canvassing boards until noon on the day after the election to verify the ballots. Fla. Stat. Ann. $\$ 101.58$. An amendment is being considered to give the canvassing boards another twenty-four hours to verify provisional ballots. George Bennett, Reforms Might Be a Pain at the Polls, Palm Beach Post, Jan. 14, 2002, 2002 WL 5523877. Either deadline seems unreasonably short. California election officials have noted that it can take weeks to process that state's provisional ballots. Id. (quoting top election official of Riverside County, California, stating that Florida's short deadlines are "setting you up for failure").

353 Fla. Stat. Ann. $\S 101.048(2)(b)(2)$. The law states that if county canvassing boards determine that the person submitting the provisional ballot was not registered or entitled to vote at the precinct in the election, the provisional ballot shall not be counted and the entire ballot shall remain in the envelope containing the Provisional Ballot Voter's Certificate and the envelope shall be marked "Rejected as Illegal." Id.

354 See Bennett, supra note 352 (attributing this interpretation of new election statute to county election official in Florida). In March 2002, the Republican majority in the Florida House defeated a proposal to allow registered voters to use provisional ballots if they attempt to vote at the wrong polling places in years when precinct boundaries are redrawn; 
sional ballots to voters who are not in their database rather than telling them the correct precinct. Moreover, due to its steady population increases, Florida will have many new precincts for voters in 2002 and 2004.355 Even faithful Florida voters who attempt to vote where they have always done so may be disappointed on future election days.

Still more mixed news concerns the requirement in Florida and Georgia reform legislation for hand recounts in close elections.356 These statutes do acknowledge both technological subsidiarity and technological fallibility, but they respond incompletely to the Bush Court's requirement of fixed rules for recounts. At present, the Georgia law does not provide rules for recounts at all-which, after the Bush decision, means that recounts are forbidden in that state. ${ }^{357}$ After its pilot project on technology, however, Georgia presumably will have time to enact such rules before the 2002 election cycle.

The Florida election reform statute does not contain rules for vote counting either. Instead, the statute explicitly assigns this task to the secretary of state. ${ }^{358}$ The task will be formidable; the new law states that the rules may not "[c]ontain a catch-all provision."359 At least the statute eschews reliance on a Rehnquist-like exaltation of technology and placement of blame on the voter. It forbids the secretary of state from creating rules that exclusively provide that "the voter must properly mark or designate his or her choice on the ballot."360 Florida law could not be clearer in its rejection of the idea that voter mistakes can be a simple excuse for declaring a vote illegal. The legislature thus took the path recommended by the Florida Task Force, which had warned, "Discarding ballots that may have errors caused by machines or faulty ballot design, rather than caused by voters, seems to be the height of bureaucratic arrogance."361

Finally, we go from the mixed news to the bad news about electoral reform in Florida and Georgia. In both states, reform is likely to lead to adoption of DRE voting systems, with all the problems associated with that computerized technology discussed in Part III. ${ }^{362}$ At

proponents argued that such changes were confusing to voters. See Mark Hollis, Major Election Changes Not in the Cards, S. Fla. Sun-Sentinel, Mar. 21, 2002, 2002 WL 2954268.

355 For example, Palm Beach County is planning to redraw and renumber its precincts and increase the number of precincts from 532 to about 700 . Id.

356 Fla. Stat. Ann. § 102.166; Ga. Code Ann. § 21-2-495(c) (Lexis Supp. 2001).

357 Ga. Code Ann. \$ 21-2-495(c); see supra Part III.A.

358 Fla. Stat. Ann. $\$ 102.166(5)(\mathrm{b})$. The secretary has proposed a draft rule in response. See Proposed Rule 1S-2.031, 28 Fla. Admin. Weekly 301 (Fla. Dep't of State Jan. 25, 2002), LEXSEE 28 FAW 301.

359 Fla. Stat. Ann. $\$ 102.166(5)(\mathrm{b})(2)$.

$360 \$ 102.166(5)(c)(2)$.

361 Florida Task Force, supra note 3 , at 48.

362 See supra notes 199-210 and accompanying text. 
present, despite the common assumption that more computerized technology always will have superior performance, the verdict on DRE voting technologies must be negative. The most reliable study of voting equipment found that the percentage of residual ballots for president produced by DRE machines was slightly better than punchcard ballots, but higher than lever machines or optical scanning technology. ${ }^{363}$ The authors of this study, experts from Caltech and MIT, concluded, "Considering some of the glowing reports about electronics following the 2000 election, we expected the DRE [machines] to do well. They did not, especially compared [with] optically scanned paper ballots." 364 While continued experience with DRE technology may improve its performance, ${ }^{365}$ these complex machines likely require greater maintenance, raise new administrative issues, and might suffer reliability problems in a real election situation. ${ }^{366}$

In Georgia, where the entire state will adopt a single voting technology, ${ }^{367}$ the secretary of state plans to use DRE machines. ${ }^{368}$ At least this would put no county at a greater disadvantage than any other, and might allow statewide experience of officials and voters to reduce residual rates over the long term. In Florida, however, the election reform law permits counties to select these machines if they wish, which will reinforce the patchwork pattern of the votingtechnology divide in that state. ${ }^{369}$ In addition, as mentioned earlier,

363 Caltech/MIT, Residual Votes, supra note 4 , at 10 . The breakdown for average residual vote by machine type for presidential elections between 1988 and 2000 was $1.9 \%$ residual votes for lever machines, $2.1 \%$ for optical scanning, $2.9 \%$ for DRE machines, and either $2.9 \%$ or $3.0 \%$ for punch-card machines, depending on the type of punch-card technology. Id. Note, however, that these results lump together optical (central) and optical (precinct) systems. Separating out the two technologies would lower the residual votes for optical (precinct) election systems.

364 Id. at 16.

365 Id. (noting that industry might fix problems with machines and that as "voters become more familiar with the newer equipment[,] errors may go down").

366 Id. (predicting that machines would demand more administration attention and thus be more prone to problems in most counties; that "electronic equipment may be harder to maintain and less reliable than a piece of paper or a mechanical device"; and that "the problem may be inherent in the technology"). The experts commented, "Electronic machines may be simply a less human friendly technology." Id.

367 Ga. Code Ann. $\$ 21-2-300$ (Lexis Supp. 2001) (requiring use of uniform voting technology throughout state by July 2004).

368 See Press Release, Secretary of State Cathy Cox, Secretary Cox: Electronic Voting Pilot Project Exit Poll Shows Strong Support for Modern "DRE" Voting Equipment (Dec. 3, 2001), http://www.sos.state.ga.us/pressrel/120301.htm (reporting results of exit poll conducted by Secretary of State showing strong public support for DRE equipment).

369 See Fla. Stat. Ann. $\S 101.5604$ (West Supp. 2002); Mark Silva, Elections Overhaul is Approved, Miami Herald, May 3, 2001, at $1 \mathrm{~A}$ ("Counties that can afford better technology than optical scanners will be permitted to install touch-screen computer voting ...."). This legislative decision ignores a central recommendation of the Florida Task Force, which urged the state to adopt unified voting technology. Florida Task Force, supra note 3, at 30. 
Florida's recount rules do a poor job of accommodating DRE systems. 370

Financial considerations make populous Florida counties especially likely to adopt DRE technology. Florida's reform law provides some state funds for initial investment in new voting equipment, but, as always has been the case, it leaves counties on their own to pay the cost of running elections. 371 This creates an incentive for counties to select new equipment with an estimated low cost of continued use, whatever its initial cost. Experts estimate the ongoing costs of a DRE machine at fifty cents to a dollar per voter; optical scanning machines, which require printing of individual ballots for each voter for both primary and general elections, cost an estimated one to two dollars per voter. ${ }^{372}$ Even though the two technologies cost similar amounts over a twenty-year period, county election administrators will find DRE machines more attractive because the state will pay a larger share of this overall amount. The temptation to reduce the ongoing per capita expenses of voting technology will be especially strong in populous counties in Florida such as Palm Beach and Miami-Dade. ${ }^{373}$ Notably, the most populous Florida counties are also the ones where large numbers of minority voters live, so that once again they are more likely to end up on the wrong side of the voting-technology divide- this time with DRE technology. ${ }^{374}$

To be sure, experimentation with voting technology, ballot design, and human-computer interfaces is necessary. Indeed, in evaluating new methods and technology, states should draw upon experts in voting technology and design. But research and testing should not take place in actual elections on a county-by-county basis, and especially not in elections for national office. When new voting technology

370 See supra notes 204-06 and accompanying text.

371 Fla. Stat. Ann. $\$ 100.011$ (West Supp. 2001).

372 See Caltech/MIT, What Chould Be, supra note 74 , at 52 . The sensitivity of county officials to ongoing costs is clear from the fact that two Florida counties with optical scanning (precinct) systems, Escambia and Manatee, chose to deactivate the feedback capability of their machines during the 2000 elections in order to save on the cost of giving voters a second chance. John Mintz \& Peter Slevin, Florida Revisited: Human Factor Was at Core of Vote Fiasco, Wash. Post, June 1, 2001, at A1. In the words of Escambia Supervisor Bonnie Jones, "People should be able to mark their vote correctly." Id. Jones criticized giving voters a chance to correct mistakes because it "increases the cost of an election." Id.

373 Palm Beach County has already announced its intention to use DRE technology. Silva, supra note 369 , at $2 \mathrm{~A}$.

374 As examples of populous counties with large numbers of minority residents, consider Miami-Dade County (total population, 2.25 million; 30.3\% nonwhite), Broward County (total population, 1.62 million; $29.4 \%$ nonwhite), and Palm Beach County (total population, 1.13 million; $20.9 \%$ nonwhite). I have based these findings on the Census 2000 Redistricting Data Summary File. See U.S. Census Bureau, Geographic Comparison Table: Florida, available at http://factfinder.census.gov (last visited Feb. 14, 2002). 
is to be used in elections, it should be employed only on a small scale in individual precincts at first, so that it can be compared with existing technologies.

One particularly useful path would be to commission independent usability analysis of proposed technologies. Usability analysis should include testing with human subjects and in circumstances that replicate those of actual elections. 375 In the absence of such testing, Florida will once again hold elections where certain counties have well-tested equipment and other counties have a question mark-albeit sometimes a high-tech question mark.

\section{CONCLUSION}

The time has come to dismantle the voting-technology divide in the United States. Berry Gordy, founder of Motown Records, once observed of his company's trademark sound, "It may be simple, but it ain't easy."376 To close the divide, states must take a number of steps, at least some of which are simple (if not easy). Drawing upon the problem areas that this Article has identified, I wish to summarize the seven most important tasks for election reform:

- Voters in statewide elections should have access to voting technologies that provide similar amounts of feedback and similar opportunities to correct ballot mistakes.

- State election systems are never perfect and require ongoing attention to problem areas. This, in turn, requires transparency-information about the past performance of system components should be widely available.

- States should seek the involvement of experts in voting technology, human-computer interface, and ballot design.

- Testing of technology, ballot design, and human-computer interfaces is necessary. Tests should not be carried out, however, on a countywide basis or in national elections.

- Beyond technology, states must pay attention to the kinds of "election ecologies" that exist at the county and precinct levels. The environments in which Americans exercise the franchise should be improved with steps such as improved training for poll workers.

375 See Caltech/MIT, What Could Be, supra note 74, at 72 ("Hardware and software must be tested on samples of human subjects-likely voters-in scientifically controlled settings."). The Caltech/MIT experts also called for testing equipment as it is actually set up and used in polling places. Id. at 73.

376 Joel Dreyfuss, Don't Get Mad, Analyze, Mobile Computing \& Communication, May 2001 , at 60 . 
- The integrity of the electoral process requires statewide attention to the voting-registration process. As part of this process, however, the state should provide feedback to individuals regarding eligibility requirements and current voter status. Moreover, greater transparency is needed about how a state maintains its registration lists.

- Political lockup can lead to unequal access to the electoral franchise. Litigation under the Equal Protection Clause and section 2 of the Voting Rights Act is an important tool to preserve the right of the people to elect their representatives in a free and unimpaired fashion.

Beyond the goals expressed in this "wish list," election-system design has a more complex, long-term obligation. At an abstract level, one can express the necessary task in this fashion: State officials must seek to structure decisionmaking power and the sharing of information within responsible agencies to ensure that system functioning improves over time. Transparency is of special importance in this context. Unless state officials and the public at large have information about system functioning, officials will continue to make small but crucial discretionary decisions incorrectly. It will be impossible to fix these unnoticed mistakes before it is too late.

The Florida election of November 2000 provided strong proof of the impact of largely hidden decisions about the election system. In its final report on the election, the U.S. Civil Rights Commission pointed to a widespread disenfranchisement of "persons whose voices were silenced in this historic election by a pattern and practice of injustice, ineptitude, and inefficiency."377 As this Article has shown, the distribution of election technology in Florida played a significant role in this disenfranchisement. The unequal access to voting violates interests in both individual participation in government and election results that reflect the voice of the people. In my view, moreover, this unequal access violates the Equal Protection Clause and section 2 of the Voting Rights Act.

Far from recognizing a right to equal access to election technology, the U.S. Supreme Court in Bush v. Gore distorted equal protection law to protect the technological "haves." The Supreme Court stopped Florida's counting of undervotes and identified a constitutionally required regime of rules for recounts. This action leaves the technology divide in Florida, and elsewhere in the United States, in-

377 Civil Rights Comm'n, supra note 22, at 99 . The Commission placed blame squarely on state officials in Florida who "failed to fulfill their duties in a manner that would prevent this disenfranchisement." Id. 
tact. It also enshrines a constitutional benchmark of hard-edged rules, which will prevent state officials and judges from taking necessary action to salvage elections when election technology failures are not anticipated.

This Article concluded by examining election reform at the federal and state levels. One of the unfortunate new trends-failure to create a unified statewide voting system-is found in Florida. Instead, Florida's election reform law permits some voters to use reliable technology and others to vote with new, largely untested high-tech devices.

As a final verdict on the November 2000 election, we can consider the opinion of President Jimmy Carter. After the election and ensuing litigation were over, Carter stated that he was "embarrassed by what happened in Florida." 378 His judgment on Florida's election system, reflecting his active role at the Carter Center monitoring elections in emerging democracies, was expressed trenchantly: "If we were invited to go into a foreign country to monitor the election, and they had similar election standards and procedures, we would refuse to participate at all." 379

The alarm call could not be clearer. A state should not be permitted to condition exercise of the electoral franchise on a voter's skills with technology, her luck, or her county of residence. Three different reports on the election agree that more than one million ballots cast nationwide on November 7, 2000 went uncounted. ${ }^{380}$ As the U.S. Civil Rights Commission concluded: "[I]t was widespread voter disenfranchisement, not the dead-heat contest, that was the extraordinary feature in the Florida election." 381 American democracy owes more to its citizens.

378 Mark Silva, Carter: Fla. Voting Too Flawed, Jan. 10, 2001, Miami Herald, at 1B.

379 Id.

380 See House Judiciary Democratic Staff Report, supra note 241, at 14 (concluding it is only possible to "partially quantify the number of ballots cast aside by machines" as "at least one million"); Carter-Ford Comm'n, supra note 235, at 50 (estimating two million residual votes); Caltech/MIT, What Could Be, supra note 74, at 8-9 (estimating between four and six million presidential votes lost). The Caltech/MIT report provided the most thorough breakdown of the lost votes of November 2000 . It estimated that: (1) 1.5 million votes were lost because of problems with voting equipment; (2) between 1.5 and 3 million votes were lost because of problems with the voter registration process; (3) between 500,000 and 1.2 million votes were lost because of problems with polling-place operations such as "lines, hours, or locations"; and (4) an unknown number of votes were lost because of problems with absentee, overseas, and military ballots. Caltech/MIT, What Could Be, supra note 74 , at $8-9$.

381 Civil Rights Comm'n, supra note 22, at 99. 